\title{
Iodine's impact on tropospheric oxidants: a global model study in GEOS-Chem
}

\author{
T. Sherwen ${ }^{1}$, M. J. Evans ${ }^{1,2}$, L. J. Carpenter ${ }^{1}$, S. J. Andrews ${ }^{1}$, R. T. Lidster ${ }^{1}$, B. Dix ${ }^{3}$, T. K. Koenig ${ }^{3,4}$, R. Sinreich ${ }^{3}$, \\ I. Ortega ${ }^{3,4}$, R. Volkamer ${ }^{3,4}$, A. Saiz-Lopez ${ }^{5}$, C. Prados-Roman ${ }^{5}$, A. S. Mahajan ${ }^{6}$, and C. Ordóñez \\ ${ }^{1}$ Wolfson Atmospheric Chemistry Laboratories (WACL), Department of Chemistry, University of York, York, \\ YO10 5DD, UK \\ ${ }^{2}$ National Centre for Atmospheric Science (NCAS), University of York, York, YO10 5DD, UK \\ ${ }^{3}$ Department of Chemistry and Biochemistry, University of Colorado, Boulder, CO 80309-0215, USA \\ ${ }^{4}$ Cooperative Institute for Research in Environmental Sciences, University of Colorado, Boulder, CO 80309-021, USA \\ ${ }^{5}$ Department of Atmospheric Chemistry and Climate, Institute of Physical Chemistry Rocasolano, CSIC, Madrid, \\ 28006, Spain \\ ${ }^{6}$ Indian Institute of Tropical Meteorology, Maharashtra, 411008, India \\ ${ }^{7}$ Met Office, FitzRoy Road, Exeter, EX1 3PB, UK
}

Correspondence to: T. Sherwen (ts551@york.ac.uk)

Received: 29 June 2015 - Published in Atmos. Chem. Phys. Discuss.: 5 August 2015

Revised: 12 January 2016 - Accepted: 21 January 2016 - Published: 2 February 2016

\begin{abstract}
We present a global simulation of tropospheric iodine chemistry within the GEOS-Chem chemical transport model. This includes organic and inorganic iodine sources, standard gas-phase iodine chemistry, and simplified higher iodine oxide $\left(\mathrm{I}_{2} \mathrm{O}_{X}, X=2,3,4\right)$ chemistry, photolysis, deposition, and parametrized heterogeneous reactions. In comparisons with recent iodine oxide (IO) observations, the simulation shows an average bias of $\sim+90 \%$ with available surface observations in the marine boundary layer (outside of polar regions), and of $\sim+73 \%$ within the free troposphere $(350 \mathrm{hPa}<p<900 \mathrm{hPa})$ over the eastern Pacific. Iodine emissions $\left(3.8 \mathrm{Tg} \mathrm{yr}^{-1}\right)$ are overwhelmingly dominated by the inorganic ocean source, with $76 \%$ of this emission from hypoiodous acid (HOI). HOI is also found to be the dominant iodine species in terms of global tropospheric $\mathrm{I}_{Y}$ burden (contributing up to $70 \%$ ). The iodine chemistry leads to a significant global tropospheric $\mathrm{O}_{3}$ burden decrease $(9.0 \%)$ compared to standard GEOS-Chem (v9-2). The iodine-driven $\mathrm{O}_{X}$ loss rate ${ }^{1}\left(748 \mathrm{Tg} \mathrm{O}_{X} \mathrm{yr}^{-1}\right)$ is due to photolysis of HOI (78\%), photolysis of OIO (21\%), and re-

\footnotetext{
${ }^{1}$ Here $\mathrm{O}_{X}$ is defined as $\mathrm{O}_{3}+\mathrm{NO}_{2}+2 \mathrm{NO}_{3}+\mathrm{PAN}+\mathrm{PMN}$ $+\mathrm{PPN}+\mathrm{HNO}_{4}+3 \mathrm{~N}_{2} \mathrm{O}_{5}+\mathrm{HNO}_{3}+\mathrm{BrO}+\mathrm{HOBr}+\mathrm{BrNO}_{2}$ $+2 \mathrm{BrNO}_{3}+\mathrm{MPN}+\mathrm{IO}+\mathrm{HOI}+\mathrm{INO}_{2}+2 \mathrm{INO}_{3}+2 \mathrm{OIO}$ $+2 \mathrm{I}_{2} \mathrm{O}_{2}+3 \mathrm{I}_{2} \mathrm{O}_{3}+4 \mathrm{I}_{2} \mathrm{O}_{4}$, where $\mathrm{PAN}=$ peroxyacetyl nitrate,
}

action between $\mathrm{IO}$ and $\mathrm{BrO}(1 \%)$. Increases in global mean $\mathrm{OH}$ concentrations $(1.8 \%)$ by increased conversion of hydroperoxy radicals exceeds the decrease in $\mathrm{OH}$ primary production from the reduced $\mathrm{O}_{3}$ concentration. We perform sensitivity studies on a range of parameters and conclude that the simulation is sensitive to choices in parametrization of heterogeneous uptake, ocean surface iodide, and $\mathrm{I}_{2} \mathrm{O}_{X}(X=2$, $3,4)$ photolysis. The new iodine chemistry combines with previously implemented bromine chemistry to yield a total bromine- and iodine-driven tropospheric $\mathrm{O}_{3}$ burden decrease of $14.4 \%$ compared to a simulation without iodine and bromine chemistry in the model, and a small increase in $\mathrm{OH}$ $(1.8 \%)$. This is a significant impact and so halogen chemistry needs to be considered in both climate and air quality models.

\section{Introduction}

The chemistry of the troposphere controls the concentration of a range of climate gases including ozone $\left(\mathrm{O}_{3}\right)$ and methane $\left(\mathrm{CH}_{4}\right)$ (Kim et al., 2011; Voulgarakis et al., 2013;

PPN = peroxypropionyl nitrate, $\mathrm{MPN}=$ methyl peroxy nitrate, and $\mathrm{MPN}=$ peroxymethacryloyl nitrate. 
Young et al., 2013), and determines human and agriculture exposure to air quality pollutants such as $\mathrm{O}_{3}$ and aerosols (Ainsworth et al., 2012; Fiore et al., 2012; Fowler et al., 2008). The chemical cycles maintaining concentrations of these atmospheric constituents are complex, and depend strongly upon the concentrations of $\mathrm{O}_{3}$ and of the hydroxyl radical $(\mathrm{OH})$ as key oxidants. Understanding the budgets and controls on these gases is therefore central to assessments of tropospheric chemistry (Voulgarakis et al., 2013).

The basic chemistry of $\mathrm{O}_{3}$ and $\mathrm{OH}$ in the troposphere is coupled, and the central aspects of this are well known (Young et al., 2013). Over the last decades significant research effort has gone into understanding the production of $\mathrm{O}_{3}$, typically over continental regions due to its adverse impact on health and food security (Ainsworth et al., 2012; Fowler et al., 2008). However, less emphasis has focused on its chemical destruction. $\mathrm{O}_{3}$ is chemically lost in the troposphere predominantly through photolysis in the presence of water or its reactions with $\mathrm{HO}_{2}$ and $\mathrm{OH}$ (Lelieveld and Dentener, 2000). However, bromine and iodine compounds have also been identified as additional sinks for $\mathrm{O}_{3}$ and as perturbations to $\mathrm{OH}$ cycling (Chameides and Davis, 1980; von Glasow et al., 2004). Of the two, iodine has arguably the more complex chemistry.

Historically, the dominant source of iodine was thought to be iodinated organic compounds from the ocean (Chuck et al., 2005; Jones et al., 2010; Law and Sturges, 2006). More recently, emission of inorganic halogen compounds $\left(\mathrm{I}_{2}\right.$ and HOI) has been identified as a significant source (Carpenter et al., 2013). Our understanding of its chemistry has been described in recent publications (Saiz-Lopez et al., 2012b; Sommariva et al., 2012). Once emitted into the atmosphere, the highly labile iodinated precursors rapidly photolyse with lifetimes of seconds (e.g. $\mathrm{I}_{2} / \mathrm{HOI}$ ) to days (e.g. $\mathrm{CH}_{3} \mathrm{I}$ ) to release atomic iodine. The iodine can catalytically destroy $\mathrm{O}_{3}$ by the reaction of $\mathrm{O}_{3}+\mathrm{I}$ to form IO, followed by secondary reactions $\left(+\mathrm{HO}_{2},+\mathrm{IO},+\mathrm{NO}_{2},+\mathrm{BrO}\right)$ which can regenerate atomic I without the abstracted oxygen. For instance IO reacts with $\mathrm{HO}_{2}$, leading to $\mathrm{HOI}$ formation, and this is rapidly photolysed to reform I causing a net conversion of $\mathrm{HO}_{2}$ to $\mathrm{OH}$.

Much of the uncertainty in iodine chemistry involves the production and fate of their higher oxides $\left(\mathrm{I}_{2} \mathrm{O}_{X}\right)$. These higher oxides are formed from a chain reaction of IO selfreactions (Sommariva et al., 2012):

$$
\begin{aligned}
& \mathrm{O}_{3}+\mathrm{I} \rightarrow \mathrm{IO}+\mathrm{O}_{2} \\
& \mathrm{IO}+\mathrm{IO} \rightarrow \mathrm{OIO}+\mathrm{I} \\
& \mathrm{IO}+\mathrm{IO} \rightarrow \mathrm{I}_{2} \mathrm{O}_{2} \\
& \mathrm{IO}+\mathrm{OIO} \rightarrow \mathrm{I}_{2} \mathrm{O}_{3} \\
& \mathrm{OIO}+\mathrm{OIO} \rightarrow \mathrm{I}_{2} \mathrm{O}_{4} .
\end{aligned}
$$

Due to their short lifetimes and low concentrations, measuring iodine species poses significant challenges and so the observational data set is sparse. For decades, measurements have focused on organic compounds and mainly $\mathrm{CH}_{3} \mathrm{I}$ (SaizLopez et al., 2012b). Technique development for in situ measurements has led to an increase in data availability over the last decade, for both organic (e.g. $\mathrm{CH}_{3} \mathrm{I}$ and $\mathrm{CH}_{2} \mathrm{IX}$, with $\mathrm{X}=\mathrm{Cl}, \mathrm{Br}, \mathrm{I}$ ) and inorganic (e.g. IO, OIO, $\mathrm{I}_{2}$ ) species (SaizLopez et al., 2012b).

Recent measurements from aircraft (Dix et al., 2013; Volkamer et al., 2015; Wang et al., 2015), balloons (Butz et al., 2009), mountain tops (Puentedura et al., 2012), ground stations (Lawler et al., 2014; Mahajan et al., 2010; Read et al., 2008), and cruises (Großmann et al., 2013; Jones et al., 2010; Mahajan et al., 2012) have enabled the development of global organic halogen emissions (Ordóñez et al., 2012; Ziska et al., 2013) and, more recently, data sets of IO observations with extensive geographical coverage (PradosRoman et al., 2015b; Volkamer et al., 2015; Wang et al., 2015).

Iodine chemistry has been evaluated by a number of box model studies (Sander et al., 1997; Mahajan et al., 2009; McFiggans et al., 2000, 2010; Read et al., 2008; Saiz-Lopez et al., 2007) and a few global model studies (Prados-Roman et al., 2015a; Saiz-Lopez et al., 2012a, 2014). The initial focus was predominantly on geographic regions with elevated concentrations (e.g. polar, Sander et al., 1997; Saiz-Lopez et al., 2007; and coastal, Mahajan et al., 2009; McFiggans et al., 2000; Saiz-Lopez et al., 2006) and attempted to explain localized chemical perturbations mainly through the use of box models.

When considered alongside bromine chemistry, box model studies have shown the magnitude of halogen-driven $\mathrm{O}_{3}$ loss processes to be up to $45 \%$ (Mahajan et al., 2009; Read et al., 2008) of the total loss. Iodine can change the local $\mathrm{HO}_{2}: \mathrm{OH}$ ratio due to the production of $\mathrm{HOI}$ from $\mathrm{HO}_{2}$ and $\mathrm{IO}$, and its subsequent photolysis to release $\mathrm{OH}$ (Bloss et al., 2005a; Chameides and Davis, 1980). Perturbation to the $\mathrm{NO}: \mathrm{NO}_{2}$ ratio has been shown to be significant at higher IO concentrations in polluted coastal locations (McFiggans et al., 2010) due to the ability of IO to oxidize $\mathrm{NO}$ into $\mathrm{NO}_{2}$, which affects $\mathrm{O}_{3}$ production. More recently, measurements in the marine boundary layer on ground-based island monitoring stations (Read et al., 2008; Mahajan et al., 2010; Gómez Martín et al., 2013), on ships (Großmann et al., 2013; Mahajan et al., 2010; Prados-Roman et al., 2015b), by balloon (Butz et al., 2009), and by aircraft (Dix et al., 2013; Volkamer et al., 2015; Wang et al., 2015) have demonstrated that these $\mathrm{O}_{3}$ loss processes also occur in remote non-coastal locations.

Recently, the role of reactive halogens have also been investigated in global chemical transport models (Parrella et al., 2012) and chemistry-climate models (Ordóñez et al., 2012; Saiz-Lopez et al., 2014). Inclusion of tropospheric bromine, iodine, and chlorine chemistry into a global model led to significant changes in the composition troposphere. Tropospheric marine average $\mathrm{O}_{3}$ columns decrease by of the order of $\sim 10 \%$ (Saiz-Lopez et al., 2012a, 2014). As in the 
box model studies, up to $\sim 30 \%$ of the $\mathrm{O}_{3}$ loss in the marine boundary layer $(900 \mathrm{hPa}<p)$ is found to be driven by halogens (Saiz-Lopez et al., 2012a, 2014). Similarly, high levels of halogen-driven $\mathrm{O}_{3}$ loss are also found in the upper troposphere $(350 \mathrm{hPa}>p>$ tropopause), with lower (10-15\%) impacts in the free troposphere $(350 \mathrm{hPa}<p<900 \mathrm{hPa})$ (Saiz-Lopez et al., 2012a, 2014).

In order to explore our current understanding of the tropospheric chemistry of iodine we present a global modelling study of tropospheric iodine chemistry, using the GEOSChem chemical transport model. The new chemistry is described in Sect. 2. Section 3 describes the comparison of modelled iodine concentrations against observations. Then Sect. 4 describes modelled global chemical distributions by family. Impacts on $\mathrm{O}_{3}$ and $\mathrm{OH}$ are described in Sect. 5. In Sect. 6 we consider interactions of iodine with bromine, and in Sect. 7 we look at key sensitivities of the simulation. Section 8 summarizes our conclusions.

\section{GEOS-Chem simulation}

We use here the GEOS-Chem (http://www.geos-chem.org) chemical transport model version v9-02, with transport driven by assimilated meteorological and surface data fields (GEOS-5) from NASA's Global Modelling and Assimilation Office (GMAO). We have adapted the existing chemistry scheme which includes $\mathrm{O}_{X}, \mathrm{HO}_{X}, \mathrm{NO}_{X}$, and VOC chemistry as described recently in Mao et al. (2013), bromine chemistry (Parrella et al., 2012), and a mass-based aerosol scheme. Stratospheric chemistry is climatologically represented based on LINOZ McLinden et al. (2000) for $\mathrm{O}_{3}$ and linearized chemistry is applied for other species with concentrations taken from the Global Modelling Initiative (GMI) as described previously (Murray et al., 2012).

Iodine tracers $\left(\mathrm{I}_{2}, \mathrm{HOI}, \mathrm{IO}, \mathrm{OIO}, \mathrm{HI}, \mathrm{INO}_{2}, \mathrm{INO}_{3}, \mathrm{I}\right.$, INO, $\mathrm{CH}_{3} \mathrm{I}, \mathrm{CH}_{2} \mathrm{I}_{2}, \mathrm{CH}_{2} \mathrm{IBr}, \mathrm{CH}_{2} \mathrm{ICl}, \mathrm{I}_{2} \mathrm{O}_{2}, \mathrm{I}_{2} \mathrm{O}_{3}, \mathrm{I}_{2} \mathrm{O}_{4}$, and "aerosol iodine") are included in the model. The modelled emissions, deposition, chemistry, photolysis, and aerosol processes of these compounds are described below. No chemical processing of iodine species is performed in the stratosphere.

Notably our work differs from recent global iodine simulations (Saiz-Lopez et al., 2014) in its treatment of $\mathrm{I}_{2} \mathrm{O}_{X}$ $(X=2,3,4)$. Our model ("Br+I") considers the photolysis of these compounds whereas their "Base" simulation does not. This leads to our simulations having a more active iodine chemistry and this is discussed in Sect. 2.4.

As well as the core simulation present in this paper ("Br+I"), comparisons with the existing standard GEOSChem simulation ("BROMINE") are presented, which includes bromine chemistry as described in Sect. 2.6. When considering the coupling of iodine and bromine, two additional simulations are included, one with just iodine chem-
Table 1. Total simulated emissions for iodinated species.

\begin{tabular}{lr}
\hline Species & $\begin{array}{r}\text { Emissions } \\
\text { Tg I yr }\end{array}$ \\
\hline $\mathrm{CH}_{3} \mathrm{I}$ & 0.26 \\
$\mathrm{CH}_{2} \mathrm{I}_{2}$ & 0.11 \\
$\mathrm{CH}_{2} \mathrm{ICl}$ & 0.18 \\
$\mathrm{CH}_{2} \mathrm{IBr}$ & 0.05 \\
$\mathrm{I}_{2}$ & 0.32 \\
$\mathrm{HOI}$ & 2.91 \\
\hline Total & 3.83 \\
\hline
\end{tabular}

istry ("IODINE") and one with no bromine or iodine chemistry ("NOHAL").

For budgets and general analysis we run the model at $2^{\circ} \times 2.5^{\circ}$ resolution for 2 years (2004 and 2005) discarding the first "spin up" year and using the final year (2005) for analysis and budgets. For the sensitivity study (Sect. 7) the model is run with the same period for "spin up" and analysis, but at $4^{\circ} \times 5^{\circ}$ resolution. The model output is discussed with focus on the marine boundary layer $(900 \mathrm{hPa}<p)$, the free troposphere $(350 \mathrm{hPa}<p<900 \mathrm{hPa})$, and upper troposphere $(350 \mathrm{hPa}>p>$ tropopause). Comparisons with observations involve separate spin-up simulations, run with the date-appropriate meteorology, sampled at the spatially and temporally nearest grid box and time step. We report here mixing ratios as pmol mol${ }^{-1}$ or nmol mol${ }^{-1}$, which are equivalent to the more widely used pptv or ppbv.

\subsection{Iodine emissions}

Both organic and inorganic iodine species (Table 1 and Fig. 1) are emitted into the atmosphere. Monthly emissions of organic iodine compounds $\left(\mathrm{CH}_{3} \mathrm{I}, \mathrm{CH}_{2} \mathrm{I}_{2}, \mathrm{CH}_{2} \mathrm{IBr}\right.$, and $\mathrm{CH}_{2} \mathrm{ICl}$ ) are taken from Ordóñez et al. (2012) which parametrizes fluxes based on chlorophyll $a$ in the Tropics and constant oceanic fluxes with 2.5 coast-to-ocean emission ratios for extratropical regions, and follows Bell et al. (2002) for $\mathrm{CH}_{3} \mathrm{I}$. Inorganic iodine compounds (HOI, $\mathrm{I}_{2}$ ), formed from the uptake of $\mathrm{O}_{3}$ to the ocean and the subsequent ocean surface reaction of $\mathrm{O}_{3}$ with iodide $\left(\mathrm{I}^{-}\right)$, are emitted as calculated from Eqs. (19) and (20) in Carpenter et al. (2013). We parametrize ocean surface $\mathrm{I}^{-}$concentration from the sea surface squared temperature relationship in Table 2 from Chance et al. (2014), the $\mathrm{O}_{3}$ concentration in the lowermost level of the model, and the $10 \mathrm{~m}$ wind speed from meteorological fields. The $10 \mathrm{~m}$ wind speed used by the parametrization is limited to a minimum of $5 \mathrm{~m} \mathrm{~s}^{-1}$ to prevent unsubstantiated emissions at low wind speeds. Annual average iodine emission fluxes are shown in Fig. 1.

Global emission totals (Table 1) are consistent with recent work (Saiz-Lopez et al., 2014) for organic iodine compounds as they also use Ordóñez et al. (2012). Inorganic 

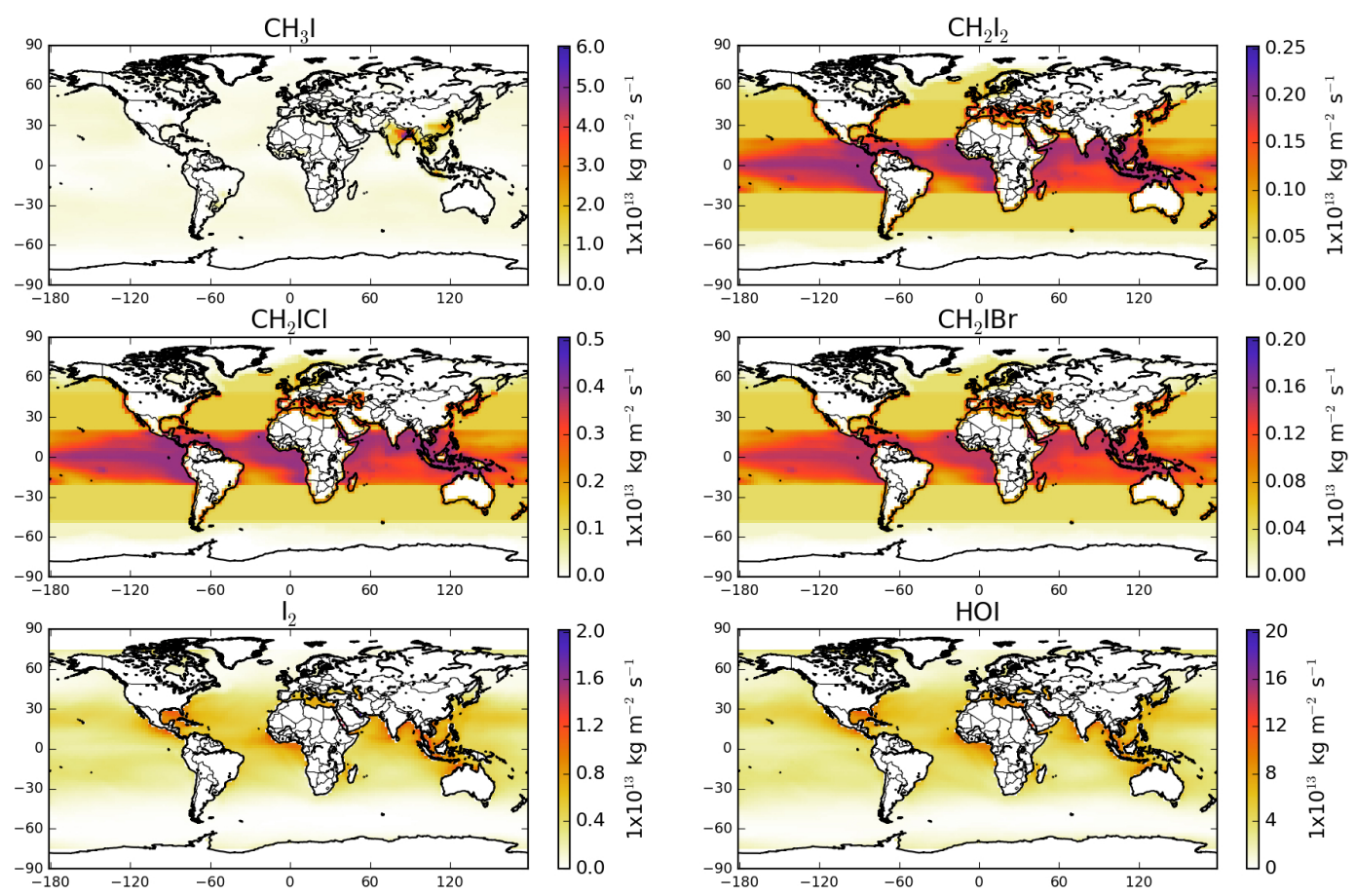

Figure 1. Annual mean surface fluxes for iodine precursors in the " $\mathrm{Br}+\mathrm{I}$ " simulation in $\mathrm{kg} \mathrm{m}^{-2} \mathrm{~s}^{-1}$.

Table 2. Henry's law coefficients and molar heats of formation of iodine species. Where Henry's law constant equals infinity a very large value is used within the model $\left(1 \times 10^{20} \mathrm{Matm}^{-1}\right)$. The $\mathrm{INO}_{2}$ Henry's law constant is assumed equal to that of $\mathrm{BrNO}_{3}$, from $\mathrm{Sander}(2015)$, by analogy. For $\mathrm{I}_{2} \mathrm{O}_{X}(X=2,3,4)$ a Henry's law constant of infinity is assumed by analogy with $\mathrm{INO}_{3} .{ }^{*}$ Effective Henry's law of $\mathrm{HI}$ is calculated for acid conditions through $K_{\mathrm{H}}^{*}(T)=K_{\mathrm{H}}(T) \times\left(1+\frac{K_{\mathrm{a}}}{\left[\mathrm{H}^{+}\right]}\right)$, where $K_{\mathrm{a}}=1 \times 10^{9} \mathrm{M}$ is the acid dissociation constant (Bell, 1973).

\begin{tabular}{llllll}
\hline Num. & Species & $\begin{array}{l}\text { Henry's law } \\
\text { constant } \\
\mathrm{Matm}^{-1}\end{array}$ & Reference & $\begin{array}{l}\text { Molar heat of } \\
\text { formation } \\
298 \mathrm{~K} / \mathrm{R}(\mathrm{K})\end{array}$ & Reference \\
\hline $\mathrm{D} 1$ & $\mathrm{HOI}$ & $1.53 \times 10^{4}$ & Sander (2015) & $-8.37 \times 10^{3}$ & Sander et al. (2006) \\
D2 & $\mathrm{HI}$ & $2.35 \times 10^{0 *}$ & Sander (2015) & $-3.19 \times 10^{3}$ & Sander et al. (2006) \\
D3 & $\mathrm{INO}_{3}$ & $\infty$ & Vogt et al. (1999) & $-3.98 \times 10^{4}$ & Kaltsoyannis and Plane (2008) \\
D4 & $\mathrm{I}_{2} \mathrm{O}_{2}$ & $\infty$ & see caption text & $-1.89 \times 10^{4}$ & Kaltsoyannis and Plane (2008) \\
D5 & $\mathrm{I}_{2}$ & $2.63 \times 10^{0}$ & Sander (2015) & $-7.51 \times 10^{3}$ & Sander et al. (2006) \\
D6 & $\mathrm{INO}_{2}$ & $3.00 \times 10^{-1}$ & see caption text & $-7.24 \times 10^{3}$ & Sander et al. (2006) \\
D7 & $\mathrm{I}_{2} \mathrm{O}_{3}$ & $\infty$ & see caption text & $-7.70 \times 10^{3}$ & Kaltsoyannis and Plane (2008) \\
D8 & $\mathrm{I}_{2} \mathrm{O}_{4}$ & $\infty$ & see caption text & $-1.34 \times 10^{4}$ & Kaltsoyannis and Plane (2008) \\
\hline
\end{tabular}

fluxes calculated in this study are $47 \%$ higher than in previous work (Saiz-Lopez et al., 2014), despite using the same parametrization (Carpenter et al., 2013; MacDonald et al., 2014). Although model-specific differences exist in sea surface temperatures, $10 \mathrm{~m}$ wind speeds, and $\mathrm{O}_{3}$ concentration, the largest differences lie in the choice of parametrization for sea surface iodide (see Sect. 7.5).

\subsection{Iodine deposition}

The model's deposition scheme has recently been updated (Amos et al., 2012). Dry deposition of the new iodine compounds is computed via the standard GEOS-Chem implementation of the "resistance-in-series" approach (Wesely, 1989) using literature Henry's law coefficients (Sander, 2015). This approach is applied to $\mathrm{I}_{2}, \mathrm{HI}, \mathrm{HOI}, \mathrm{INO}_{2}, \mathrm{INO}_{3}$, $\mathrm{I}_{2} \mathrm{O}_{2}, \mathrm{I}_{2} \mathrm{O}_{3}$, and $\mathrm{I}_{2} \mathrm{O}_{4}$. Aerosol iodine is assumed to have the same wet deposition properties as sulfate aerosol.

Wet deposition is calculated for $\mathrm{I}_{2}, \mathrm{HI}, \mathrm{HOI}, \mathrm{INO}_{2}, \mathrm{INO}_{3}$, $\mathrm{I}_{2} \mathrm{O}_{2}, \mathrm{I}_{2} \mathrm{O}_{3}$, and $\mathrm{I}_{2} \mathrm{O}_{4}$ for both large-scale (frontal) and convective rain by applying scavenging in and below clouds (Liu et al., 2001) using species-specific values for Henry's law coefficients (Sander, 2015; Vogt et al., 1999) and molar heats 
Table 3. Bimolecular and unimolecular iodine reactions. These are given in the Arrhenius form with the rate equal to $A \cdot \exp \left(\frac{E a}{R T}\right)$. Unknown values are represented by a dash and these set to zero in the model, reducing the exponent to 1 . The bimolecular reactions with an $M$ in them represent termolecular reactions where the pressure dependence is not known or are unimolecular decomposition reactions. Reactions included, but not in IUPAC/JPL, are discussed further in Sect. A1.1.

\begin{tabular}{|c|c|c|c|c|}
\hline Rxn ID & Reaction & $\begin{array}{l}A \\
\mathrm{~cm}^{3} \text { molecules }\end{array}$ & $\begin{array}{r}E a / R \\
\mathrm{~K}\end{array}$ & Citation \\
\hline M1 & $\mathrm{I}+\mathrm{O}_{3} \rightarrow \mathrm{IO}+\mathrm{O}_{2}$ & $2.10 \times 10^{-11}$ & -830 & Atkinson et al. (2007) \\
\hline M2 & $\mathrm{I}+\mathrm{HO}_{2} \rightarrow \mathrm{HI}+\mathrm{O}_{2}$ & $1.50 \times 10^{-11}$ & -1090 & Sander et al. (2011) \\
\hline M3 & $\mathrm{I}_{2}+\mathrm{OH} \rightarrow \mathrm{HOI}+\mathrm{I}$ & $2.10 \times 10^{-10}$ & - & Atkinson et al. (2007) \\
\hline M4 & $\mathrm{HI}+\mathrm{OH} \rightarrow \mathrm{I}+\mathrm{H}_{2} \mathrm{O}$ & $1.60 \times 10^{-11}$ & 440 & Atkinson et al. (2007) \\
\hline M5 & $\mathrm{HOI}+\mathrm{OH} \rightarrow \mathrm{IO}+\mathrm{H}_{2} \mathrm{O}$ & $5.00 \times 10^{-12}$ & - & Riffault et al. (2005) \\
\hline M6 & $\mathrm{IO}+\mathrm{HO}_{2} \rightarrow \mathrm{HOI}+\mathrm{O}_{2}$ & $1.40 \times 10^{-11}$ & 540 & Atkinson et al. (2007) \\
\hline M7 & $\mathrm{IO}+\mathrm{NO} \rightarrow \mathrm{I}+\mathrm{NO}_{2}$ & $7.15 \times 10^{-12}$ & 300 & Atkinson et al. (2007) \\
\hline M8 & $\mathrm{HO}+\mathrm{CH}_{3} \mathrm{I} \rightarrow \mathrm{H}_{2} \mathrm{O}+\mathrm{I}\left(\mathrm{CH}_{2} \mathrm{I}\right)$ & $4.30 \times 10^{-12}$ & -1120 & Atkinson et al. (2008) \\
\hline M9 & $\mathrm{INO}+\mathrm{INO} \rightarrow \mathrm{I}_{2}+2 \mathrm{NO}$ & $8.40 \times 10^{-11}$ & -2620 & Atkinson et al. (2007) \\
\hline M10 & $\mathrm{INO}_{2}+\mathrm{INO}_{2} \rightarrow \mathrm{I}_{2}+2 \mathrm{NO}_{2}$ & $4.70 \times 10^{-12}$ & -1670 & Atkinson et al. (2007) \\
\hline M11 & $\mathrm{I}_{2}+\mathrm{NO}_{3} \rightarrow \mathrm{I}+\mathrm{INO}_{3}$ & $1.50 \times 10^{-12}$ & - & Atkinson et al. (2007) \\
\hline M12 & $\mathrm{INO}_{3}+\mathrm{I} \rightarrow \mathrm{I}_{2}+\mathrm{NO}_{3}$ & $9.10 \times 10^{-11}$ & -146 & Kaltsoyannis and Plane (2008) \\
\hline M13 & $\mathrm{I}+\mathrm{BrO} \rightarrow \mathrm{IO}+\mathrm{Br}$ & $1.20 \times 10^{-11}$ & - & Sander et al. (2011) \\
\hline M14 & $\mathrm{IO}+\mathrm{Br} \rightarrow \mathrm{I}+\mathrm{BrO}$ & $2.70 \times 10^{-11}$ & - & Bedjanian et al. (1997) \\
\hline M15 & $\mathrm{IO}+\mathrm{BrO} \rightarrow \mathrm{Br}+\mathrm{I}+\mathrm{O}_{2}$ & $3.00 \times 10^{-12}$ & 510 & Atkinson et al. (2007) \\
\hline M16 & $\mathrm{IO}+\mathrm{BrO} \rightarrow \mathrm{Br}+\mathrm{OIO}$ & $1.20 \times 10^{-11}$ & 510 & Atkinson et al. (2007) \\
\hline M17 & $\mathrm{OIO}+\mathrm{OIO} \rightarrow \mathrm{I}_{2} \mathrm{O}_{4}$ & $1.50 \times 10^{-10}$ & - & Gómez Martín et al. (2007) \\
\hline M18 & $\mathrm{OIO}+\mathrm{NO} \rightarrow \mathrm{NO}_{2}+\mathrm{IO}$ & $1.10 \times 10^{-12}$ & 542 & Atkinson et al. (2007) \\
\hline M19 & $\mathrm{IO}+\mathrm{IO} \rightarrow \mathrm{I}+\mathrm{OIO}$ & $2.16 \times 10^{-11}$ & 180 & Atkinson et al. (2007) \\
\hline M20 & $\mathrm{IO}+\mathrm{IO} \stackrel{\mathrm{M}}{\rightarrow} \mathrm{I}_{2} \mathrm{O}_{2}$ & $3.24 \times 10^{-11}$ & 180 & Atkinson et al. (2007) \\
\hline M21 & $\mathrm{IO}+\mathrm{OIO} \stackrel{\mathrm{M}}{\longrightarrow} \mathrm{I}_{2} \mathrm{O}_{3}$ & $1.50 \times 10^{-10}$ & - & Gómez Martín et al. (2007) \\
\hline M22 & $\mathrm{I}_{2} \mathrm{O}_{2} \stackrel{\mathrm{M}}{\rightarrow} \mathrm{IO}+\mathrm{IO}$ & $1.00 \times 10^{12}$ & -9770 & Ordóñez et al. (2012) \\
\hline M23 & $\mathrm{I}_{2} \mathrm{O}_{2} \stackrel{\mathrm{M}}{\rightarrow} \mathrm{OIO}+\mathrm{I}$ & $2.50 \times 10^{14}$ & -9770 & Ordóñez et al. (2012) \\
\hline M24 & $\mathrm{I}_{2} \mathrm{O}_{4} \stackrel{\mathrm{M}}{\rightarrow} 2 \mathrm{OIO}$ & $3.80 \times 10^{-2}$ & - & Kaltsoyannis and Plane (2008) \\
\hline M25 & $\mathrm{INO}_{2} \stackrel{\mathrm{M}}{\longrightarrow} \mathrm{I}+\mathrm{NO}_{2}$ & $9.94 \times 10^{17}$ & -11859 & McFiggans et al. (2000) \\
\hline M26 & $\mathrm{INO}_{3} \stackrel{\mathrm{M}}{\rightarrow} \mathrm{IO}+\mathrm{NO}_{2}$ & $2.10 \times 10^{15}$ & -13670 & Kaltsoyannis and Plane (2008) \\
\hline
\end{tabular}

of formation (Kaltsoyannis and Plane, 2008; Sander, 2015) as shown in Table 2. Fractionation between gas and liquid on ice is considered (Parrella et al., 2012; Stuart and Jacobson, 2003). Aerosol iodine is assumed to have the same dry deposition properties as sulfate aerosol.

\subsection{Iodine chemistry scheme}

The gas phase iodine chemistry is shown in Tables 3 and 4 . We include all iodine reactions presented by recent IUPAC (Atkinson et al., 2007, 2008) and JPL 10-6 (Sander et al., 2011) compilations relevant to the troposphere. Some additional reactions are included based on recent work (Sommariva et al., 2012; von Glasow et al., 2002) as justified in Sect. A1.1. Reactions within aerosol following uptake of species (HI, HOI, $\mathrm{INO}_{2}, \mathrm{INO}_{3}$ ) and processing of higher iodine oxides $\left(\mathrm{I}_{2} \mathrm{O}_{X}, X=2,3,4\right)$ after formation of $\mathrm{I}_{2} \mathrm{O}_{X}$ are not treated explicitly but are parametrized as described in Sect. 2.5.

\subsection{Photolysis rates}

Photolysis reactions are summarized in Table 5. Photolysis rates are calculated online using the standard FAST-J code implementation in GEOS-Chem (Mao et al., 2010). Crosssections are processed to the seven wavelength bins used by FAST-J (Bian and Prather, 2002). For most cross-sections JPL 10-6 (Sander et al., 2011) values were used. For $\mathrm{I}_{2} \mathrm{O}_{X}$ $(X=2,3,4)$ we assume the same absorption cross-section as $\mathrm{INO}_{3}$, an approach used previously (Bloss et al., 2010). For most species $\left(\mathrm{I}_{2}, \mathrm{HOI}, \mathrm{IO}\right.$, OIO, INO, $\mathrm{INO}_{2}, \mathrm{I}_{2} \mathrm{O}_{2}, \mathrm{CH}_{3} \mathrm{I}$, $\mathrm{CH}_{2} \mathrm{I}_{2}, \mathrm{CH}_{2} \mathrm{IBr}$, and $\mathrm{CH}_{2} \mathrm{ICl}$ ) we assume a quantum yield of 1 , but for $\mathrm{INO}_{3}$ we use a quantum yield of 0.21 (Sander et al., 2011). 
Table 4. Termolecular iodine reactions. The lower pressure limit rate $\left(k_{0}\right)$ is given by: $A_{0} \cdot \exp \left(\frac{E a}{R T}\right) \cdot\left(\frac{300}{T}\right)^{x}$. The high-pressure limit is given by $k_{\infty} . F_{\mathrm{c}}$ characterizes the fall-off curve of the reaction as described by Atkinson et al. (2007). Unknown values are represented by a dash and these set to zero in the model, reducing the exponent to 1 .

\begin{tabular}{llllllll}
\hline Rxn ID & Reaction & $\begin{array}{l}A_{0} \\
\mathrm{~cm}^{6} \text { molecules }\end{array}$
\end{tabular}

Table 5. Photolysis reactions of iodine species. For $\mathrm{I}_{2} \mathrm{O}_{X}(X=2$, $3,4)$ the cross-section of $\mathrm{INO}_{3}$ is used as described in Sect. 2.4.

\begin{tabular}{lll}
\hline ID & Reaction & Reference cross-section \\
\hline $\mathrm{J} 1$ & $\mathrm{I}_{2}+h v \rightarrow 2 \mathrm{I}$ & Sander et al. (2011) \\
$\mathrm{J} 2$ & $\mathrm{HOI}+h v \rightarrow \mathrm{I}+\mathrm{OH}$ & Sander et al. (2011) \\
$\mathrm{J} 3$ & $\mathrm{IO}+h v \rightarrow \mathrm{I}+\left[\mathrm{O}_{3}\right]$ & Sander et al. (2011) \\
$\mathrm{J} 4$ & $\mathrm{OIO}+h v \rightarrow \mathrm{I}+\mathrm{O}_{2}$ & Sander et al. (2011) \\
$\mathrm{J} 5$ & $\mathrm{INO}+h v \rightarrow \mathrm{I}+\mathrm{NO}$ & Sander et al. (2011) \\
$\mathrm{J} 6$ & $\mathrm{INO}_{2}+h v \rightarrow \mathrm{I}+\mathrm{NO}_{2}$ & Sander et al. (2011) \\
$\mathrm{J} 7$ & $\mathrm{INO}_{3}+h v \rightarrow \mathrm{I}+\mathrm{NO}_{3}$ & Sander et al. (2011) \\
$\mathrm{J} 8$ & $\mathrm{I}_{2} \mathrm{O}_{2}+h v \rightarrow \mathrm{I}+\mathrm{OIO}$ & see caption \\
$\mathrm{J} 9$ & $\mathrm{CH}_{3} \mathrm{I}+h v \rightarrow \mathrm{I}+\mathrm{CH}_{2} \mathrm{O}_{2}$ & Sander et al. (2011) \\
$\mathrm{J} 10$ & $\mathrm{CH}_{2} \mathrm{I}_{2}+h v \rightarrow 2 \mathrm{I}+\left(\mathrm{CH}_{2}\right)$ & Sander et al. (2011) \\
$\mathrm{J} 11$ & $\mathrm{CH}_{2} \mathrm{ICl}+h v \rightarrow \mathrm{I}+\left(\mathrm{CH}_{2} \mathrm{Cl}\right)$ & Sander et al. (2011) \\
$\mathrm{J} 12$ & $\mathrm{CH}_{2} \mathrm{IBr}+h v \rightarrow \mathrm{I}+\left(\mathrm{CH}_{2} \mathrm{Br}\right)$ & Sander et al. (2011) \\
$\mathrm{J} 20$ & $\mathrm{I}_{2} \mathrm{O}_{4}+h v \rightarrow 2 \mathrm{OIO}$ & see caption \\
$\mathrm{J} 21$ & $\mathrm{I}_{2} \mathrm{O}_{3}+h v \rightarrow \mathrm{OIO}+\mathrm{IO}$ & see caption \\
\hline & &
\end{tabular}

\subsection{Heterogeneous processes}

In line with previous studies (McFiggans et al., 2000), we consider that the uptake of $\mathrm{HOI}, \mathrm{INO}_{2}$, and $\mathrm{INO}_{3}$ leads to the recycling of iodine back into the gas phase as $1 / 2 \mathrm{I}_{2}$ on sea-salt aerosol alone, whereas irreversible loss via uptake of $\mathrm{HI}$ leads to the generation of aerosol phase iodine. Uptake of $\mathrm{I}_{2} \mathrm{O}_{X}(X=2,3,4)$ also leads to the generation of aerosol phase iodine (on any aerosol). Heterogeneous uptake rates are computed using the GEOS-Chem standard code (Jacob, 2000) from reactive uptake coefficients $(\gamma)$. Reactions considered and values of $\gamma$ used are based on recommendations and previous studies (see Table 6 and Sect. A1.2).

\subsection{Model bromine chemistry}

The bromine simulation in GEOS-Chem is described in Parrella et al. (2012) and this bromine chemistry is included in the simulations "BROMINE" and " $\mathrm{Br}+\mathrm{I}$ " in the paper. Parrella et al. (2012) presented a range of comparisons against satellite $\mathrm{BrO}$ observations. Although in general the model reproduces many of the features, there is a systematic underestimation of tropospheric $\mathrm{BrO}$. New aircraft observations show that tropospheric BrO (Volkamer et al., 2015; Wang et al., 2015) may be higher than within our simulation. Our simulation also underestimates surface $\mathrm{BrO}$ observed in the tropical Atlantic marine boundary layer $(900 \mathrm{hPa}<p)\left(\sim 2 \mathrm{pmol} \mathrm{mol}^{-1}\right.$, Read et al., 2008) by a ratio of $\sim 5\left(0.4 \mathrm{pmol} \mathrm{mol}^{-1}\right)$. We consider the uncertainty in $\mathrm{BrO}$ concentration on our simulation as a part of our sensitivity study in Sect. 7.

\section{Iodine model results and observation comparisons}

In this section we describe and evaluate our iodine simulation ("Br+I"), which includes both iodine and bromine chemistry (Sect. 2.6). We initially focus on observational constraints for those iodine compounds that are directly emitted (Sect. 3.1), and then on the only secondary product which has been comprehensively observed (IO) (Sect. 3.2). We then turn to the averaged distribution of modelled iodinated compounds throughout the troposphere (Sect. 4).

\subsection{Emitted iodine compounds}

Figures 2 and 3 show annually averaged zonal (Fig. 2) and surface concentrations (Fig. 3) of organic and inorganic iodine precursors and their degradation products. These figures clearly illustrate the oceanic nature of iodine source species $\left(\mathrm{CH}_{3} \mathrm{I}, \mathrm{CH}_{2} \mathrm{I}_{2}, \mathrm{CH}_{2} \mathrm{ICl}, \mathrm{CH}_{2} \mathrm{IBr}, \mathrm{HOI}, \mathrm{I}_{2}\right)$, with the highest concentrations over the tropical ocean. These plots also highlight the contribution of the included terrestrial $\mathrm{CH}_{3} \mathrm{I}$ paddy field source $(25 \%)$ to global $\mathrm{CH}_{3} \mathrm{I}$ concentrations from the Bell et al. (2002) emissions included in Ordóñez et al. (2012).

The emissions used here for organic iodine species have been assessed in Ordóñez et al. (2012). We briefly present here a comparison between observations of $\mathrm{CH}_{3} \mathrm{I}$ and $\mathrm{CH}_{2} \mathrm{ICl}$ (Fig. 4) made during the UK Combined Airborne Studies in the Tropics (CAST) campaign over the tropical Pacific (Guam) from January and February of 2014. These observations were made by gas chromatography mass spectrometry as described in Andrews et al. (2015), using whole air samples from the Facility Airborne Atmospheric Measurement BAe 146-301 atmospheric research aircraft with techniques described in Andrews et al. (2013). The model shows an ability to capture the trend of decreasing concentration profile with height, but appears to underestimate the $\mathrm{CH}_{3} \mathrm{I}$ concentrations (Fig. 4). Concentrations of $\mathrm{CH}_{2} \mathrm{ICl}$ ap- 

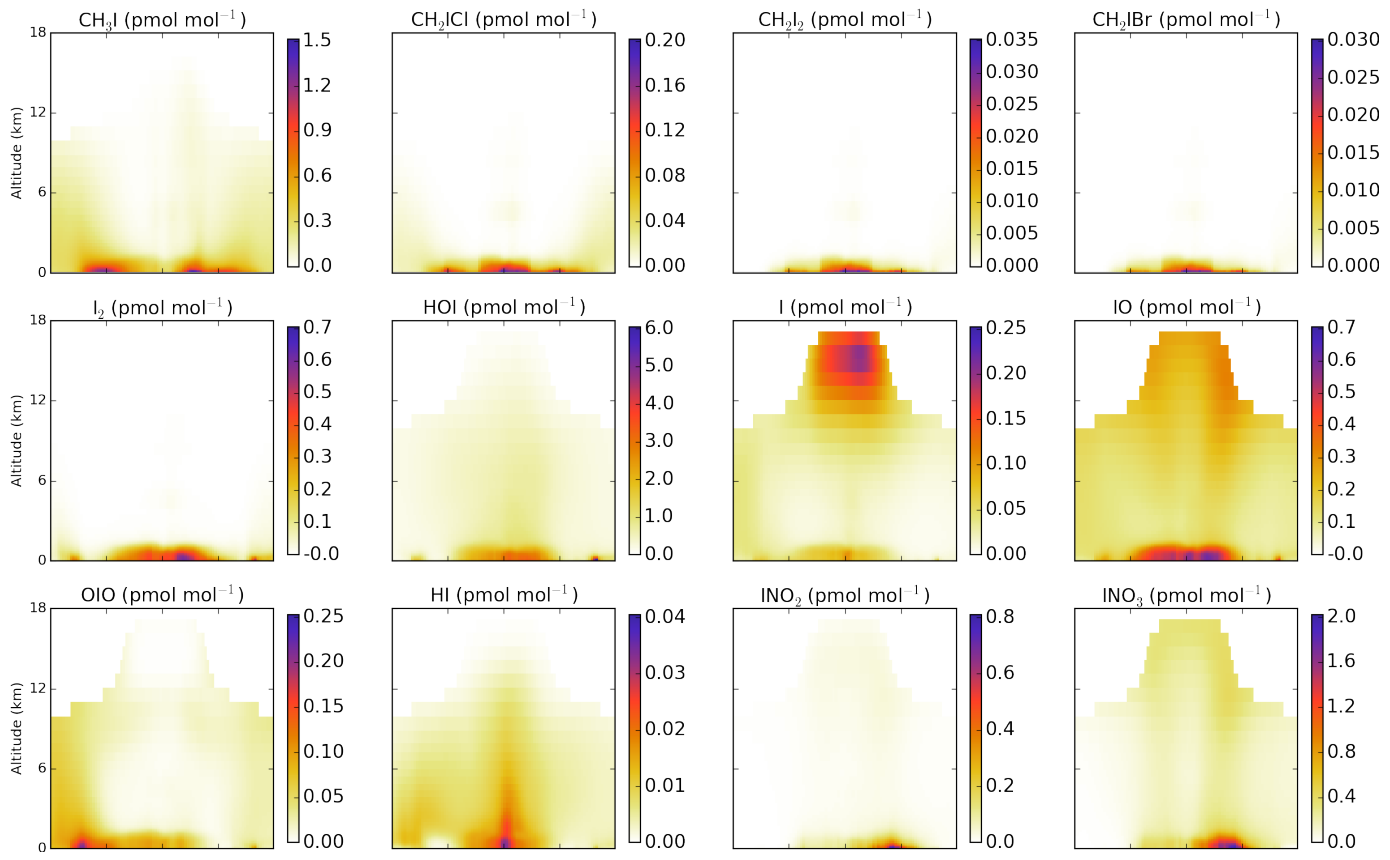

Figure 2. Annual mean zonal tropospheric mixing ratios for precursor and reactive iodine compounds ( $\mathrm{pmol} \mathrm{mol}^{-1}$ ) in the simulation with both iodine and bromine chemistry (" $\mathrm{Br}+\mathrm{I}$ "). No calculations of concentrations are made within the stratosphere and so that region is left blank.

Table 6. Heterogeneous reactions of iodine species. Where measured values have not been reported estimated values are used and no reference is given, further detail on uptake choices is in Sect. A1.2. Asterisked $\left.{ }^{*}\right)$ reactions proceed only on sea-salt aerosols.

\begin{tabular}{llll}
\hline $\mathrm{ID}$ & Reaction & Reactive uptake coefficient $(\gamma)$ & Reference \\
\hline $\mathrm{K} 1$ & $\mathrm{HI} \rightarrow$ iodine aerosol & $0.10^{*}$ & Crowley et al. $(2010)$ \\
$\mathrm{K} 2$ & $\mathrm{INO}_{3} \rightarrow 0.5 \mathrm{I}_{2}$ & $0.01^{*}$ & see caption text \\
$\mathrm{K} 3$ & $\mathrm{HOI} \rightarrow 0.5 \mathrm{I}_{2}$ & $0.01^{*}$ & Sander et al. $(2011)$ \\
$\mathrm{K} 4$ & $\mathrm{INO}_{2} \rightarrow 0.5 \mathrm{I}_{2}$ & $0.02^{*}$ & see caption text \\
$\mathrm{K} 5$ & $\mathrm{I}_{2} \mathrm{O}_{2} \rightarrow$ iodine aerosol & 0.02 & see caption text \\
$\mathrm{K} 6$ & $\mathrm{I}_{2} \mathrm{O}_{4} \rightarrow$ iodine aerosol & 0.02 & see caption text \\
$\mathrm{K} 7$ & $\mathrm{I}_{2} \mathrm{O}_{3} \rightarrow$ iodine aerosol & 0.02 & see caption text \\
\hline
\end{tabular}

pear to be better simulated in the marine boundary layer $(900 \mathrm{hPa}<p)$ where measurements are available (Fig. 4). Although not definitive, this brief comparison suggests that the model, if anything, underestimates the concentration of organic iodine.

The first in situ remote open ocean $\mathrm{I}_{2}$ concentration measurements were made at Cape Verde (Lawler et al., 2014). This data set reported concentrations increasing between dusk and dawn in the range 0.2 to $1.7 \mathrm{pmol} \mathrm{mol}^{-1}$ for the two separate measurement campaigns in May 2007 and May 2009 respectively. Our model captures the diurnal variation in $\mathrm{I}_{2}$ of essentially zero during the day and increasing $\mathrm{I}_{2}$ concentration during the night, peaking just before dawn, but ranges between 2.5 and $7.5 \mathrm{pmol} \mathrm{mol}^{-1}$. Some component of this overestimate probably relates to the model's iodine heterogenous recycling which assumes $100 \%$ conver- sion of $\mathrm{HOI}, \mathrm{INO}_{3}$, and $\mathrm{INO}_{2}$ into $1 / 2 \mathrm{I}_{2}$ rather than $\mathrm{ICl}$ and $\mathrm{IBr}$ which has been observed in laboratory studies (Braban et al., 2007).

\subsection{Iodine oxide (IO) observations}

Effectively, the only secondary iodine compound that has been observed and reported is IO. A comparison of a range of surface observations is shown in Fig. 5. Good agreement is seen in the West Pacific (TransBrom, Großmann et al., 2013) and tropical Atlantic at Cape Verde (Mahajan et al., 2010; Read et al., 2008), but the model has a generally high bias compared with other data sets (HALOCast-P, Mahajan et al., 2012; Malasapina, Prados-Roman et al., 2015b, TORERO ship Volkamer et al., 2015).

Biases between the daytime modelled and measured IO at Cape Verde and during the TransBrom cruise biases are 

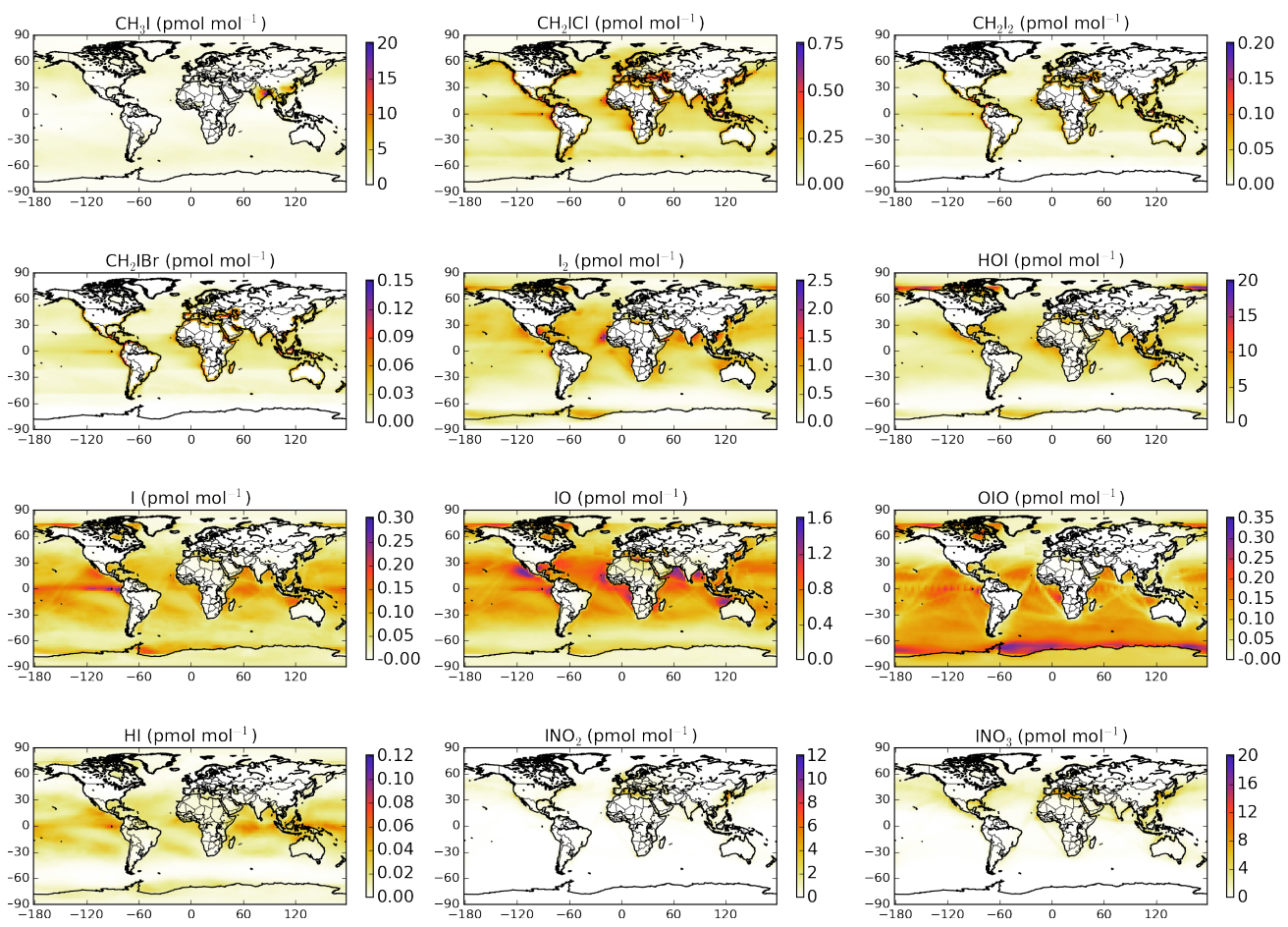

Figure 3. Annual mean surface mixing ratios for precursor and reactive iodine $\left(\mathrm{pmol} \mathrm{mol}^{-1}\right)$ in the simulation with both iodine and bromine chemistry ("Br+I").
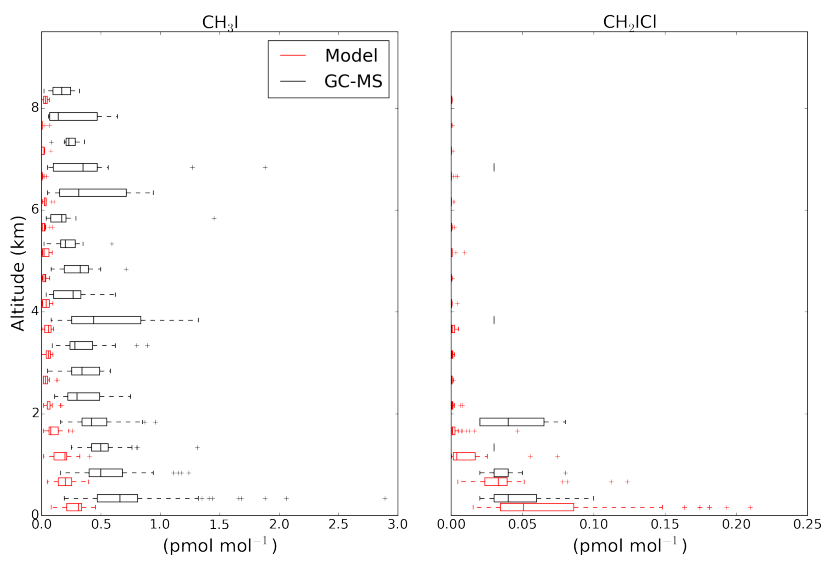

Figure 4. Vertical comparison of observations from the CAST (Combined Airborne Studies in the Tropics) campaign in the midPacific (Guam). The observations are shown in black and simulated values with both iodine and bromine chemistry (" $\mathrm{Br}+\mathrm{I}$ ") in red. Values are considered in $0.5 \mathrm{~km}$ bins, with observations and modelled values at the same location and time (as described in Sect. 2) shown side-by-side around the mid-point of each bin. The observations are from the FAAM BAE-146 research aircraft whole air samples analysed by Gas Chromatography-Mass Spectrometry (GC-MS). The box plot extents give the inter-quartile range, with the median shown within the box. The whiskers give the most extreme point within 1.5 times the inter-quartile range. within $\sim 22$ and $\sim 16 \%$ respectively. However, the model overestimates the Malasapina cruise IO concentrations (bias $\sim+50$ to $250 \%$ ), TORERO ship observations (bias $+114-$ $164 \%$ ), and both under- and over- estimates values from the HALOCast-P cruise (bias -0.92 to $280 \%$ ). When all observations are latitudinally averaged (onto a $20^{\circ}$ grid), an average bias of $\sim+90 \%$ is found.

In Fig. 6 we show a comparison with recent aircraft IO observations from the TORERO aircraft campaign (Volkamer et al., 2015; Wang et al., 2015), which took place over the eastern Pacific. The model captures the vertical profile of IO but overestimates the observations (average bias of $+82 \%$ within the binned comparison). Biases in the comparison are greatest (bias $=+125 \%$ ) in the marine boundary layer $(900 \mathrm{hPa}<p)$ and lowest (bias $=+73 \%)$ in the free troposphere $(350 \mathrm{hPa}<p<900 \mathrm{hPa})$. The median bias in the upper troposphere $(350 \mathrm{hPa}>p>$ tropopause $)$ is $+95 \%$.

From these comparisons it is evident that the model has some skill in simulating the average global surface distribution of IO (within a factor of 2) and similar skill at reproducing average vertical profiles. However, there is significant variability between locations, data sets, and measurement groups. Increased global coverage, especially vertically, and inter-comparison of observational techniques are needed to better constrain the IO distribution. 
Table 7. Comparison between global tropospheric $\mathrm{O}_{X}$ budgets of simulations "BROMINE", "Br+I", "IODINE", and "NOHAL" are described here. "BROMINE" includes just bromine chemistry, "Br+I" includes both iodine and bromine chemistry, "IODINE" only includes iodine chemistry, and "NOHAL" is simulation without iodine or bromine chemistry. Recent average model values from Young et al. (2013) are also shown. For the $\mathrm{IO}+\mathrm{BrO}$ halogen crossover reaction we allocate half the $\mathrm{O}_{3}$ loss to bromine and half to iodine. Values are rounded to the nearest integer value.

\begin{tabular}{|c|c|c|c|c|c|}
\hline Scenario & "NOHAL" & "IODINE" & "BROMINE" & "Br+I" & ACCENT Young et al. (2013) \\
\hline $\mathrm{O}_{3}$ burden $(\mathrm{Tg})$ & 390 & 357 & 367 & 334 & $340 \pm 40$ \\
\hline \multicolumn{6}{|l|}{$\mathrm{O}_{X}$ chemical sources $\left(\mathrm{Tg} \mathrm{yr}^{-1}\right)$} \\
\hline $\mathrm{NO}+\mathrm{HO}_{2}$ & 3667 & 3680 & 3512 & 3529 & - \\
\hline $\mathrm{NO}+\mathrm{CH}_{3} \mathrm{O}_{2}$ & 1332 & 1383 & 1269 & 1307 & - \\
\hline Other $\mathrm{O}_{X}$ sources & 502 & 518 & 505 & 521 & - \\
\hline Total chemical $\mathrm{O}_{X}$ sources $\left(\mathrm{PO}_{X}\right)$ & 5501 & 5581 & 5286 & 5357 & $5110 \pm 606$ \\
\hline \multicolumn{6}{|l|}{$\mathrm{O}_{X}$ chemical sinks $\left(\mathrm{Tg} \mathrm{yr}^{-1}\right)$} \\
\hline $\mathrm{O}_{3}+h v+\mathrm{H}_{2} \mathrm{O} \rightarrow 2 \mathrm{OH}+\mathrm{O}_{2}$ & 2579 & 2271 & 2425 & 2119 & - \\
\hline $\mathrm{O}_{3}+\mathrm{HO}_{2} \rightarrow \mathrm{OH}+\mathrm{O}_{2}$ & 1391 & 1186 & 1274 & 1080 & - \\
\hline $\mathrm{O}_{3}+\mathrm{OH} \rightarrow \mathrm{HO}_{2}+\mathrm{O}_{2}$ & 687 & 627 & 621 & 560 & - \\
\hline $\mathrm{HOBr}+h v \rightarrow \mathrm{Br}+\mathrm{OH}$ & - & - & 166 & 143 & - \\
\hline $\mathrm{HOBr}+\mathrm{HBr} \rightarrow \mathrm{Br}_{2}+\mathrm{H}_{2} \mathrm{O}$ (aq. aerosol) & - & - & 8 & 8 & - \\
\hline $\mathrm{BrO}+\mathrm{BrO} \rightarrow 2 \mathrm{Br}+\mathrm{O}_{2}$ & - & - & 12 & 10 & - \\
\hline $\mathrm{BrO}+\mathrm{BrO} \rightarrow \mathrm{Br}_{2}+\mathrm{O}_{2}$ & - & - & 3 & 3 & - \\
\hline $\mathrm{BrO}+\mathrm{OH} \rightarrow \mathrm{Br}+\mathrm{HO}_{2}$ & - & - & 6 & 5 & - \\
\hline $\mathrm{IO}+\mathrm{BrO} \rightarrow \mathrm{Br}+\mathrm{I}+\mathrm{O}_{2}$ & - & - & - & 7 & - \\
\hline Other bromine $\mathrm{O}_{X}$ sinks & - & - & 1 & 1 & - \\
\hline Total bromine $\mathrm{O}_{X}$ sinks & - & - & 195 & 178 & - \\
\hline $\mathrm{HOI}+h v \rightarrow \mathrm{I}+\mathrm{OH}$ & - & 639 & - & 583 & - \\
\hline $\mathrm{HOI} \rightarrow 0.5 \mathrm{I}_{2}$ (sea-salt aerosol) & - & 2 & - & 2 & - \\
\hline $\mathrm{IO}+\mathrm{BrO} \rightarrow \mathrm{Br}+\mathrm{I}+\mathrm{O}_{2}$ & - & - & - & 7 & - \\
\hline $\mathrm{OIO}+h v \rightarrow \mathrm{I}+\mathrm{O}_{2}$ & - & 114 & - & 156 & - \\
\hline Other iodine $\mathrm{O}_{X}$ sinks & - & 1 & - & 1 & - \\
\hline Total iodine $\mathrm{O}_{X}$ sinks & - & 756 & - & 748 & - \\
\hline Other $\mathrm{O}_{X}$ sinks & 176 & 181 & 172 & 179 & - \\
\hline Total chem. $\mathrm{O}_{X}$ sinks $\left(\mathrm{LO}_{X}\right)$ & 4833 & 5021 & 4687 & 4864 & $4668 \pm 727$ \\
\hline $\mathrm{O}_{3} \mathrm{P}\left(\mathrm{O}_{X}\right)-\mathrm{L}\left(\mathrm{O}_{X}\right)\left(\mathrm{Tg} \mathrm{yr}^{-1}\right)$ & 668 & 560 & 599 & 493 & $618 \pm 251$ \\
\hline $\mathrm{O}_{3}$ Dry deposition $\left(\mathrm{Tg} \mathrm{yr}^{-1}\right)$ & 949 & 850 & 886 & 791 & $1003 \pm 200$ \\
\hline $\mathrm{O}_{3}$ Lifetime (days) & 25 & 22 & 24 & 22 & $22 \pm 2$ \\
\hline $\mathrm{O}_{3}$ STE $\left(\mathrm{PO}_{X}-\mathrm{LO}_{X}\right.$-Dry dep. $)\left(\mathrm{Tg} \mathrm{yr}^{-1}\right)$ & 281 & 290 & 287 & 298 & $552 \pm 168$ \\
\hline
\end{tabular}

\section{Modelled distribution of iodinated compounds}

We now analyse the modelled distribution of iodinated compounds. We start with the total gas phase inorganic iodine $\mathrm{I}_{Y}$ species $\left(2 \mathrm{I}_{2}+\mathrm{HOI}+\mathrm{IO}+\mathrm{OIO}+\mathrm{HI}\right.$ $\left.+\mathrm{INO}+\mathrm{INO}_{2}+\mathrm{INO}_{3}+2 \mathrm{I}_{2} \mathrm{O}_{2}+2 \mathrm{I}_{2} \mathrm{O}_{3}+2 \mathrm{I}_{2} \mathrm{O}_{4}\right)$ and then move to the distribution of the $\mathrm{IO}_{X}(\mathrm{I}+\mathrm{IO})$ family.

\subsection{Total inorganic iodine $\left(I_{Y}\right)$}

The modelled iodine system is schematically shown in Fig. 7. Iodine emissions total $3.8 \mathrm{Tg} \mathrm{Iyr}^{-1}$ with most of this $\left(3.2 \mathrm{Tg} \mathrm{Iyr}^{-1}\right)$ coming from the inorganic source $(84 \%)$.
This is comparable to the $83 \%$ calculated by Prados-Roman et al. (2015b) (Ocean only, $\left.60^{\circ} \mathrm{N}-60^{\circ} \mathrm{S}\right)$. Most (56\%) of the emissions occur in the Tropics $\left(22^{\circ} \mathrm{S}\right.$ to $\left.22^{\circ} \mathrm{N}\right)$. Our emissions, which include inorganic emissions, compare with reported values of $1.8 \mathrm{Tg} \mathrm{Iyr}^{-1}$ (Saiz-Lopez et al., 2012a) and 2.6 $\mathrm{Tg} \mathrm{I} \mathrm{yr}^{-1}$ (Saiz-Lopez et al., 2014) which also include an inorganic source. Previous studies that did not consider an inorganic iodine source give values of $0.58 \mathrm{Tg} \mathrm{I} \mathrm{yr}^{-1}$ (Ordóñez et al., 2012), and $0.65 \mathrm{Tg} \mathrm{I} \mathrm{yr}^{-1}$ (Jones et al., 2010), consistent with our organic emissions. HOI represents the single largest source of oceanic iodine $(76 \%)$ with averaged oceanic emissions of $1.4 \times 10^{8}$ atoms $(\mathrm{I}) \mathrm{cm}^{-2} \mathrm{~s}^{-1}$. This value 

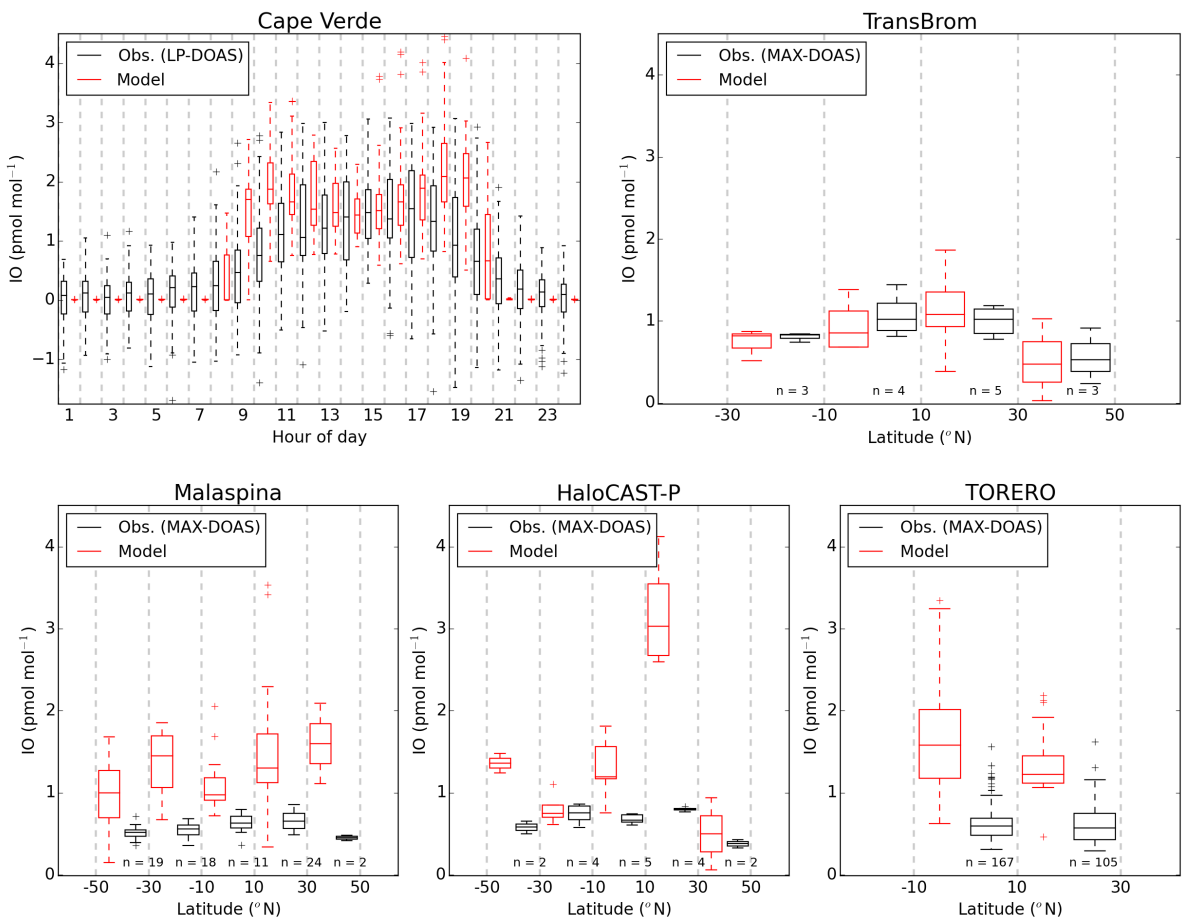

Figure 5. Iodine oxide (IO) surface observations (black) by campaign compared against the simulation with both iodine and bromine chemistry ("Br+I", red). Cape Verde measurements are shown against hour of day and others are shown as a function of latitude. Values are considered in $20^{\circ}$ bins, with observations and modelled values at the same location and time (as described in Sect. 2) shown side-by-side around the mid-point of each bin. Extents of bins are highlighted with grey dashed lines. Observations are from Cape Verde (Tropical Atlantic, Mahajan et al., 2010; Read et al., 2008), Transbrom (West Pacific, Großmann et al., 2013), the Malaspina circumnavigation (Prados-Roman et al., 2015b), HaloCAST-P (East Pacific, Mahajan et al., 2012), and TORERO ship (East Pacific, Volkamer et al., 2015). Number of data points within latitudinal bin are shown as " $n$ ". The boxplot extents give the inter-quartile range, with the median shown within the box. The whiskers give the most extreme point within 1.5 times the inter-quartile range.

is towards the lower end of flux values required to reproduce IO observations in recent box modelling studies (Großmann et al., 2013; Jones et al., 2010; Mahajan et al., 2009).

Annual mean surface concentrations (Fig. 3) of IO are ubiquitously found over the oceans at $\sim 0.25-1 \mathrm{pmol} \mathrm{mol}^{-1}$. Minor species (e.g. HI, OIO) are modelled at greatest mixing ratios over the tropical oceans and towards the poles. Iodine compounds are formed through interacts with $\mathrm{NO}_{X}$ $\left(\mathrm{INO}_{3} / \mathrm{INO}_{2}\right)$ peaking in the Northern Hemisphere in polluted oceanic regions. However, due to limited or nonexistent measurements of these species in the remote marine boundary layer, these species offer limited ability to constrain the modelled values.

Iodine deposition is predominantly through $\mathrm{HOI}(51 \%)$. The remainder is mostly through deposition of $\mathrm{INO}_{3}(20 \%)$ and aerosol iodine formed by heterogeneous loss of gaseous iodine $\left(\mathrm{HI}, \mathrm{I}_{2} \mathrm{O}_{X}\right)(24 \%)$. The majority of the deposition sink is back into the ocean $(91 \%)$. The global $\mathrm{I}_{Y}$ lifetime is 3.3 days but where depositional scavenging is weakest (upper troposphere, $350 \mathrm{hPa}>p>$ tropopause) this can increase by 2 orders of magnitudes.
Figures 8 and 9 show the average vertical and zonal distribution of iodine compounds through the troposphere. As expected given the surface source, the concentration of iodine drops with altitude. This drop is rapid across the top of the boundary layer. The concentrations of the short-lived source gases $-\mathrm{CH}_{2} \mathrm{I} X$ (where $X=\mathrm{Cl}, \mathrm{Br}, \mathrm{I}$ ) and $\mathrm{I}_{2}$ - are negligible outside of the lowest model levels but the concentrations of others $\left(\mathrm{CH}_{3} \mathrm{I}\right.$ and $\left.\mathrm{HOI}\right)$ persist further through the column. For $\mathrm{CH}_{3} \mathrm{I}$ this is due to its longer lifetime of $\sim 4$ days. However, the lifetime of $\mathrm{HOI}$ is short $(\sim 4 \mathrm{~min})$ and its persistence at higher altitudes reflects secondary chemical sources. From the top of the boundary layer to $\sim 10 \mathrm{~km}$ the $\mathrm{I}_{Y}$ profile is flat due to the rapid convective mixing within the Tropics. However, above this mixing zone the concentrations decrease. The inorganic iodine within the tropical $\left(22^{\circ} \mathrm{N}-22^{\circ} \mathrm{S}\right)$ upper troposphere $(>10 \mathrm{~km})$ is approximately equally sourced from upwards $I_{Y}$ flux $\left(6.6 \mathrm{Gg} \mathrm{yr}^{-1}\right)$ and organic iodine photolysis $\left(7.9 \mathrm{Gg} \mathrm{yr}^{-1}\right)$, overwhelmingly of $\mathrm{CH}_{3} \mathrm{I}$. Overall, atmospheric iodine is dominated by three IOy species (HOI, $\mathrm{IO}$, and $\left.\mathrm{INO}_{3}\right)$ with $\mathrm{HOI}$ representing the greatest fraction $(\sim 70 \%)$ in the free troposphere $(350 \mathrm{hPa}<p<900 \mathrm{hPa})$. 


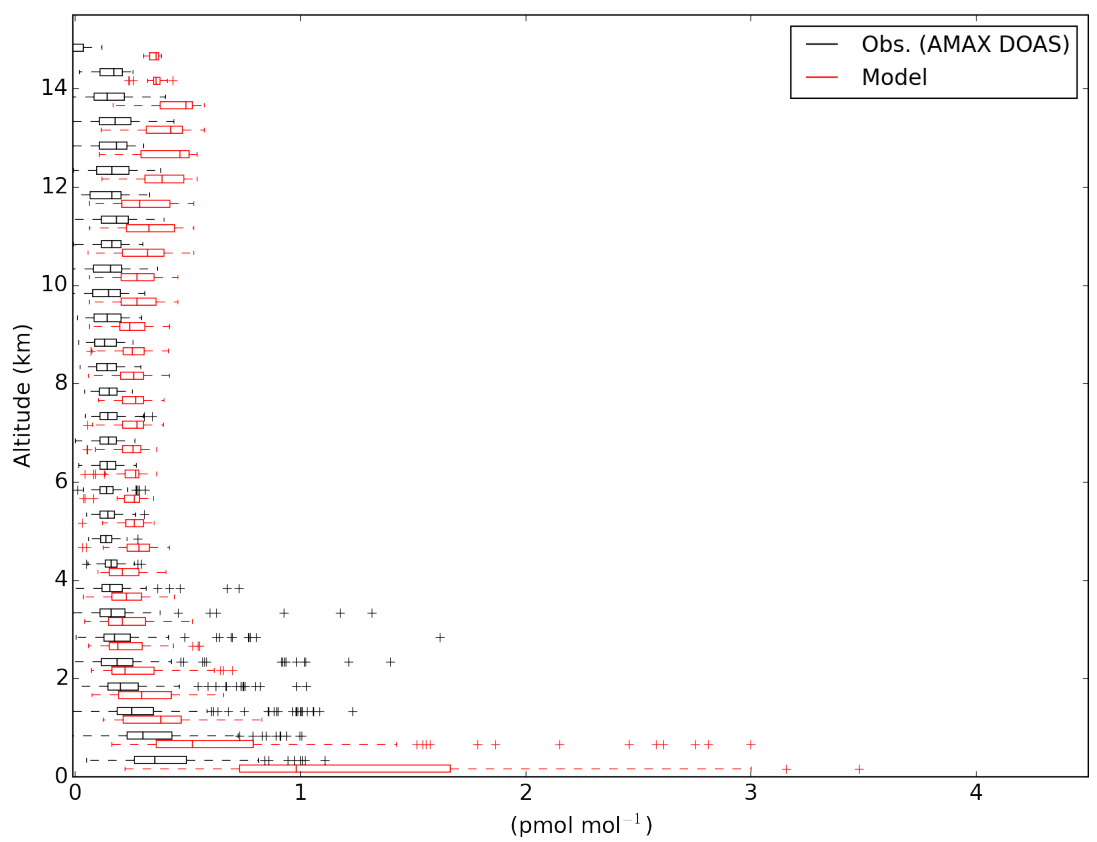

Figure 6. Vertical comparison of the simulation with both iodine and bromine chemistry ("Br+I") and measured iodine oxide (IO) during TORERO aircraft campaign (Volkamer et al., 2015; Wang et al., 2015). Model and observations are in red and black respectively. Values are considered in $0.5 \mathrm{~km}$ bins, with observations and modelled values at the same location and time (as described in Sect. 2) shown side-by-side around the mid-point of each bin. Measurements were taken aboard the NSF/NCAR GV research aircraft by the University of Colorado airborne Multi-Axis DOAS instrument (CU AMAX-DOAS) in the eastern Pacific in January and February 2012 (Volkamer et al., 2015 ; Wang et al., 2015). The boxplot extents give the inter-quartile range, with the median shown within the box. The whiskers give the most extreme point within 1.5 times the inter-quartile range.

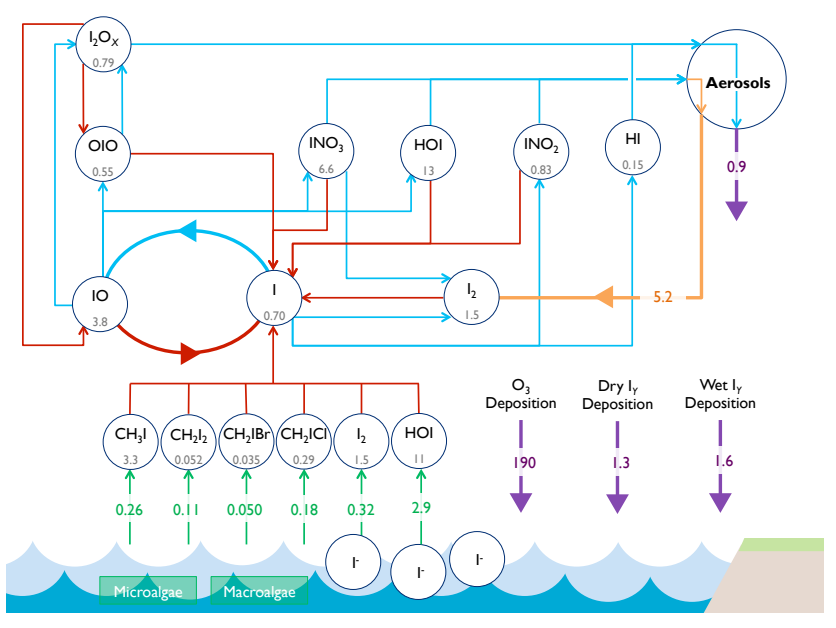

Figure 7. Schematic representation of implemented iodine chemistry in the simulation with both iodine and bromine chemistry ("Br+I"). Average global annual mean burdens (GgI) are shown below key $\mathrm{I}_{Y}$ species, with fluxes $\left(\mathrm{Tg} \mathrm{I} \mathrm{yr}^{-1}\right)$ shown on arrows. Red lines, photolysis; blue lines, chemical pathways; green lines, emission source; orange lines, heterogeneous pathway; purple lines, depositional pathway. This equates to a total iodine source and sink of $3.8 \mathrm{Tg} \mathrm{I} \mathrm{yr}^{-1} . \mathrm{O}_{3}$ deposition in $\mathrm{Tg}$ is also shown to illustrate the driving force behind the inorganic emissions.

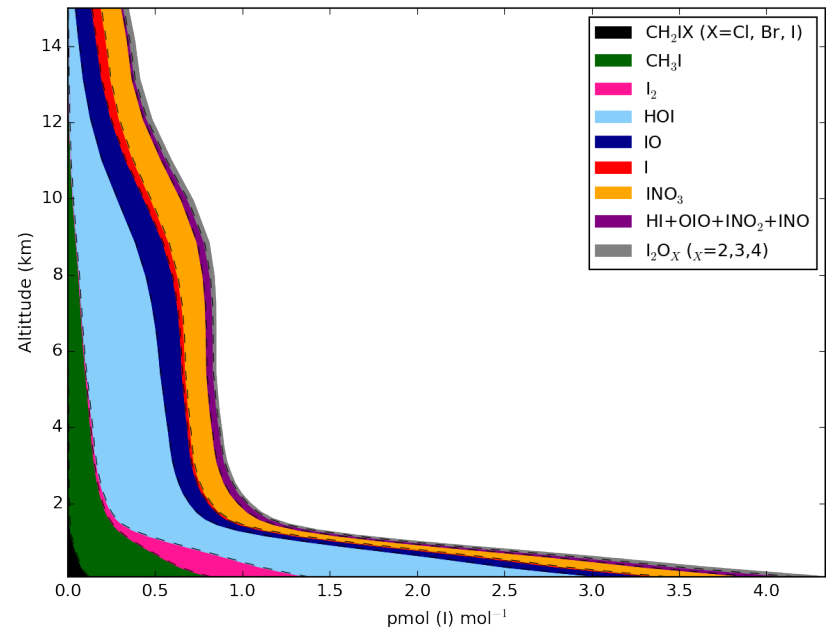

Figure 8. Global annual mean gas-phase iodine speciation with altitude in the simulation with both iodine and bromine chemistry ("Br+l"). Mixing ratios are shown in $\mathrm{pmol} \mathrm{mol}^{-1}$, with higher iodine oxides $\left(\mathrm{I}_{2} \mathrm{O}_{X}(X=2,3,4)\right)$ and di-halogenated organics $\left(\mathrm{CH}_{2} \mathrm{I} X(X=\mathrm{Cl}, \mathrm{Br}, \mathrm{I})\right)$ grouped. 


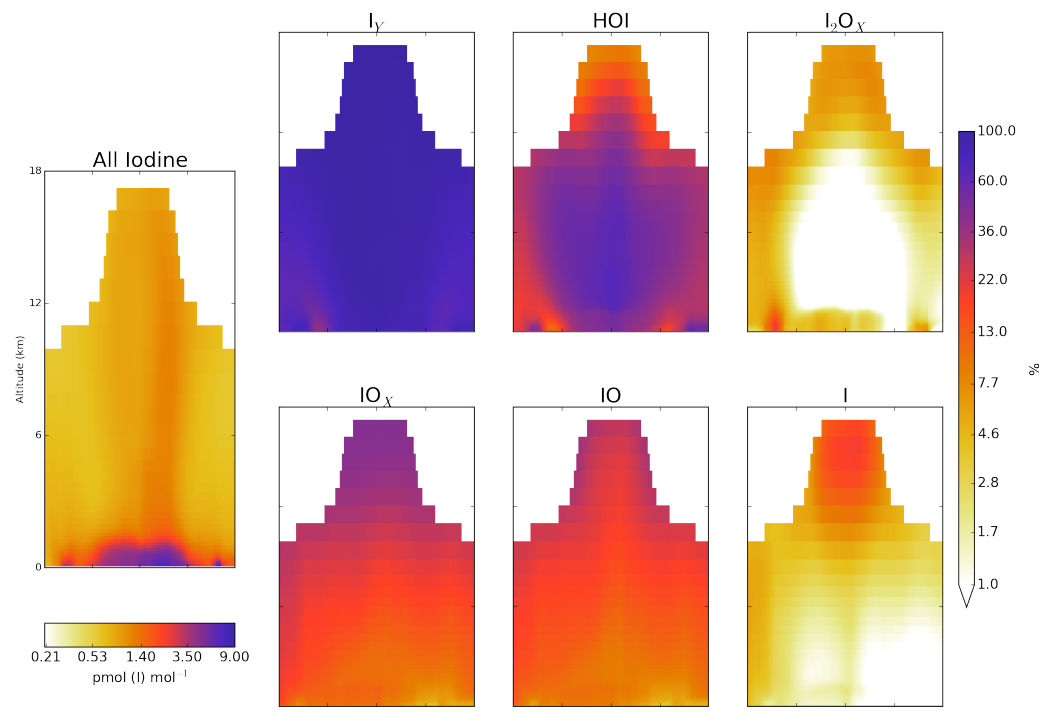

Figure 9. Zonal breakdown of global annual mean iodine speciation by family in the "Br+I" simulation. First panel shows total gas phase iodine concentration and the following panels show percentage of different compounds to this. Total gas phase iodine ("All Iodine") $=$ $\mathrm{CH}_{3} \mathrm{I}+2 \mathrm{CH}_{2} \mathrm{I}_{2}+\mathrm{CH}_{2} \mathrm{IBr}+\mathrm{CH}_{2} \mathrm{ICl}+2 \mathrm{I}_{2}+\mathrm{HOI}+\mathrm{IO}+\mathrm{OIO}+\mathrm{HI}+\mathrm{INO}_{2}+\mathrm{INO}_{3}+2 \mathrm{I}_{2} \mathrm{O}_{2}+2 \mathrm{I}_{2} \mathrm{O}_{3}+2 \mathrm{I}_{2} \mathrm{O}_{4}+\mathrm{I}+\mathrm{INO} ; \mathrm{I}_{Y}=2 \mathrm{I}_{2}+\mathrm{HOI}+$ $\mathrm{IO}+\mathrm{OIO}+\mathrm{HI}+\mathrm{INO}+\mathrm{INO}_{2}+\mathrm{INO}_{3}+2 \mathrm{I}_{2} \mathrm{O}_{2}+2 \mathrm{I}_{2} \mathrm{O}_{3}+2 \mathrm{I}_{2} \mathrm{O}_{4} ; \mathrm{IO}_{X}=\mathrm{I}+\mathrm{IO}$.
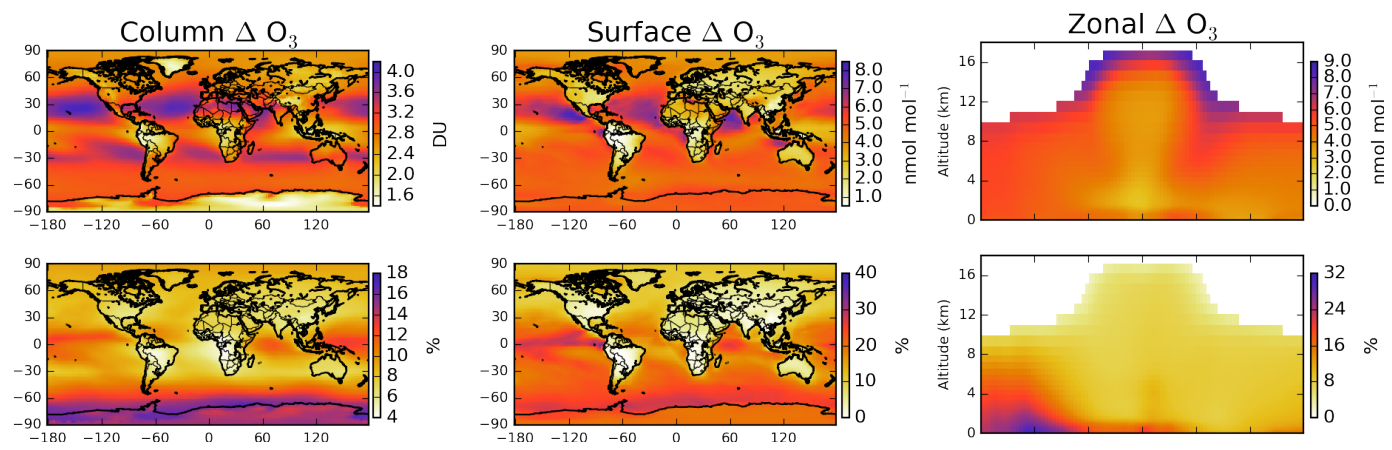

Figure 10. Decreases in annual mean tropospheric column, surface, and zonal $\mathrm{O}_{3}$ with inclusion of iodine ("Br+I"-"BROMINE") chemistry are shown on left, middle, and right panels respectively. Upper panels show changes in Dobson units or nmol mol ${ }^{-1}$ and lower panels show changes in percentage terms.

\subsection{The iodine oxide family: $\mathrm{IO}_{X}(\mathrm{I}+\mathrm{IO})$}

Globally, $\mathrm{IO}_{X}$ production is dominated by inorganic iodine $\mathrm{I}_{Y}$ photolysis (HOI, $76 \%$; OIO, $11 \%$ ). The major loss route for $\mathrm{IO}_{X}$ is HOI production through $\mathrm{IO}$ reaction with $\mathrm{HO}_{2}$ $(77 \%)$, with additional loss routes through self-reaction, reaction with $\mathrm{NO}_{X}$, and $\mathrm{BrO}$ contributing $10,7.7$, and $4.6 \%$ respectively.

The global average $\mathrm{IO}_{X}$ lifetime with respect to chemical loss is $\sim 1 \mathrm{~min}$, but increases within the tropical upper troposphere ( $350 \mathrm{hPa}>p>$ tropopause) (up to nine times) and beyond latitudes of $80^{\circ} \mathrm{N}$ and $\mathrm{S}$ (up to four times) due to colder temperatures. The major IO formation route $\left(\mathrm{I}+\mathrm{O}_{3}\right)$ slows in these regions due to colder temperatures. This moves the partitioning of $\mathrm{IO}_{X}$ from $\mathrm{IO}$ to $\mathrm{I}$. As the $\mathrm{IO}_{X}$ loss routes proceed predominantly through $\mathrm{IO}$, the overall $\mathrm{IO}_{X}$ lifetime in- creases. This causes an increase in the annually averaged I to IO ratio which peaks with a ratio of $0.7-1.4$ within the tropical upper troposphere ( $350 \mathrm{hPa}>p>$ tropopause). This is at the lower end of the daytime range of 1-4 previously calculated (Saiz-Lopez et al., 2014). As described in Sect. 4.1, the $\mathrm{I}_{Y}$ (and thus the $\mathrm{IO}_{X}$ ) in this region is approximately evenly sourced from photolysis of transported organic iodine species and direct transport of $I_{Y}$.

\section{Impact of iodine on $\mathrm{O}_{3}$ and $\mathrm{OH}$}

$\mathrm{O}_{3}$ and $\mathrm{OH}$ are two key parameters for climate and air quality. Previous studies (Bloss et al., 2005b; Saiz-Lopez et al., 2008, 2012a) have identified significant impacts of iodine on these compounds. Here we compare our model predictions 

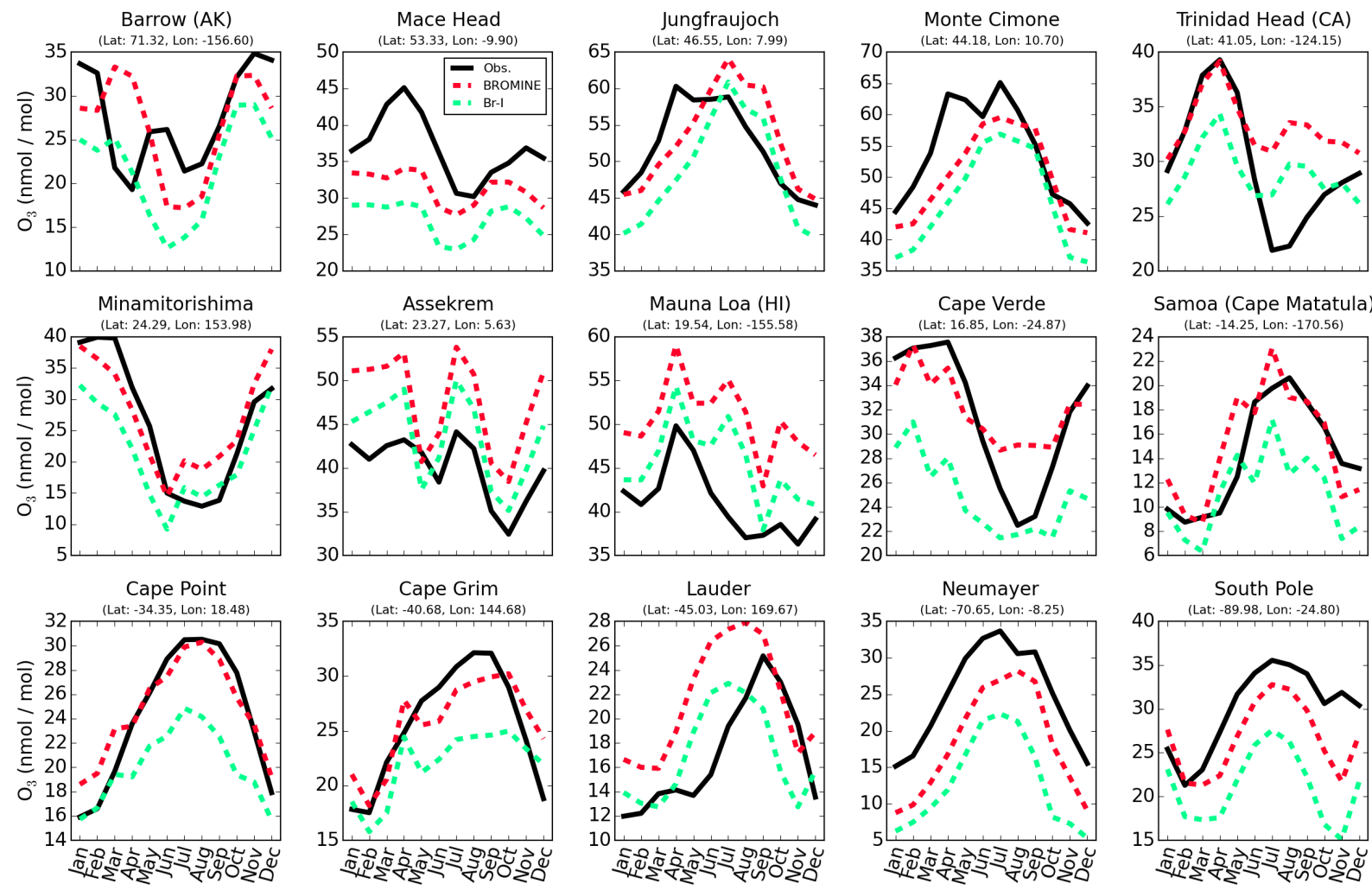

Figure 11. Seasonal cycle of near-surface $\mathrm{O}_{3}$ at a range of Global Atmospheric Watch (GAW) sites (Sofen and Evans, 2015). Observational data shown are a 6-year monthly average (2006-2012). Model data are for 2005. Data are from GAW compile and processed as described in Sofen and Evans (2015). Red indicates standard GEOS-Chem (v9-2) including bromine chemistry ("BROMINE") and green with inclusion of iodine chemistry ("Br+I").

to available observational constraints and then diagnose the model change.

\subsection{Impact on $\mathrm{O}_{3}$}

On inclusion of iodine, the calculated global tropospheric $\mathrm{O}_{3}$ burden drops from 367 to $334 \mathrm{Tg}$ (9.0\%). Figure 10 shows the annual average tropospheric column, surface, and zonal change in $\mathrm{O}_{3}$. On average the $\mathrm{O}_{3}$ burdens in the marine boundary layer $(900 \mathrm{hPa}<p)$ decreased by $19.5 \%$, by $9.8 \%$ in the free troposphere $(350 \mathrm{hPa}<p<900 \mathrm{hPa})$, and $6.2 \%$ in the upper troposphere ( $350 \mathrm{hPa}>p>$ tropopause). The decrease is greater in the Southern Hemisphere $(9.5 \%)$, than the Northern Hemisphere (8.5\%).

Surface (lowermost model level) $\mathrm{O}_{3}$ shows an average decrease of $3.5 \mathrm{nmol} \mathrm{mol}^{-1}$ globally, with large spatial variability (Fig. 11) with a greater decrease over the oceans $(21 \%)$ than the land $(7.3 \%)$. Comparing against the Global Atmospheric Watch (GAW, Sofen and Evans, 2015) surface $\mathrm{O}_{3}$ observations (Fig. 11), there is no obvious decrease in the ability of the model to capture seasonality in surface $\mathrm{O}_{3}$ although there is systematic decrease in $\mathrm{O}_{3}$ concentration with the inclusion of iodine.
Figure 12 shows a comparison between a selection of annually averaged $\mathrm{O}_{3}$ sonde profiles for the same year (2005, World Ozone and Ultraviolet Data Centre WOUDC, 2014) and our model simulation with and without iodine. A decrease in $\mathrm{O}_{3}$ concentration is evident throughout the troposphere (average of $3.1 \mathrm{nmol} \mathrm{mol}^{-1}$ ). As with comparison of surface observations (Fig. 12), no clear decline in model skill at capturing annual sonde profiles is apparent on inclusion of iodine, with some locations improving and others degrading. An exception to this is $\mathrm{O}_{3}$ observations south of $60^{\circ} \mathrm{S}$ at the surface where biases are increased and in the tropical free troposphere $(350 \mathrm{hPa}<p<900 \mathrm{hPa})$ where model $\mathrm{O}_{3}$ biases are decreased.

\section{$5.2 \mathrm{O}_{3}$ budget}

We diagnose the impact of iodine on $\mathrm{O}_{3}$ by calculating the model's tropospheric odd oxygen $\left(\mathrm{O}_{X}\right)$ budget in Table 7 . Here we define $\mathrm{O}_{X}$ as defined in footnote 1 .

Iodine provides a global tropospheric $\mathrm{O}_{X}$ loss of $748 \mathrm{Tg} \mathrm{yr}^{-1}$ (15\% of the total). This is significantly larger than the $178 \mathrm{Tg} \mathrm{yr}^{-1}$ from bromine chemistry and is comparable to the sink from the $\mathrm{O}_{3}+\mathrm{OH}$ reaction. Overwhelmingly this loss is from the photolysis of $\mathrm{HOI}$ after its produc- 


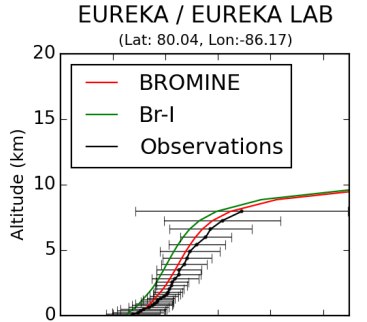

HILO

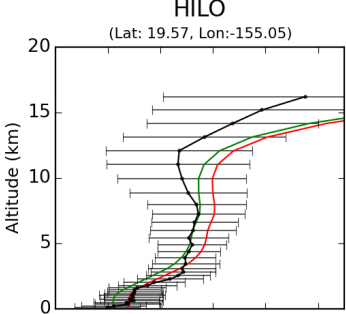

LAUDER

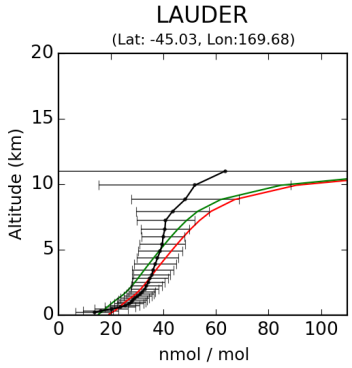

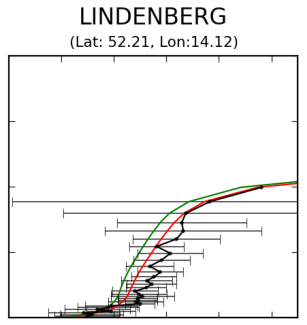

ASCENSION ISLAND (Lat: - 7.98 , Lon:-14.42)

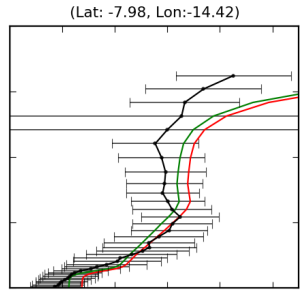

MARAMBIO (Lat: - 64.23 , Lon:-56.62)

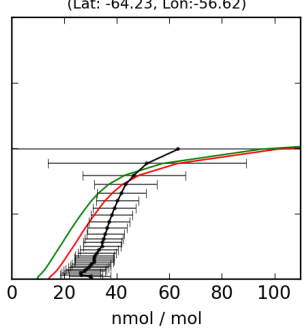

WALLOPS ISLAND

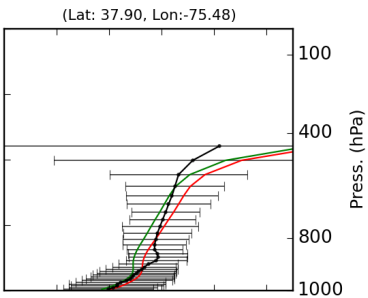

SAMOA

(Lat: -14.25, Lon:-170.56)

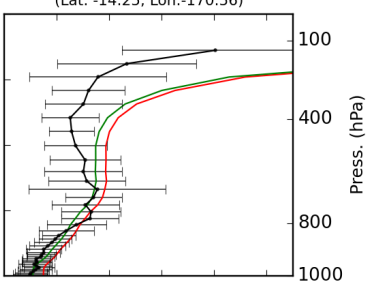

NEUMAYER

(Lat: - 70.65 , Lon:-8.25)

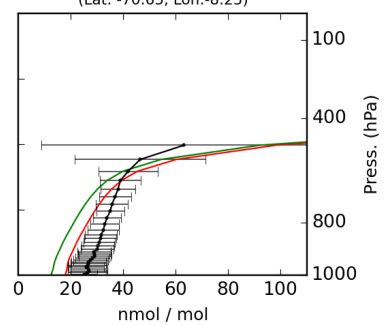

Figure 12. Comparison between annual modelled $\mathrm{O}_{3}$ profiles and sonde data (2005, WOUDC, 2014). Profiles shown are the annual mean of available observations from World Ozone and Ultraviolet Radiation Data Centre WOUDC (2014) and model data for 2005 at given locations. Red indicates standard GEOS-Chem (v9-2) including bromine chemistry ("BROMINE") and green with inclusion of iodine chemistry ("Br+I"). Observations (in black) show mean concentrations with upper and lower quartiles given by whiskers.

tion from the reaction of $\mathrm{IO}$ with $\mathrm{HO}_{2}$. The $\mathrm{O}_{3}$ production term increases slightly $(\sim 1 \%)$ with the inclusion of iodine reflecting small changes in the total reactive nitrogen partitioning.

Iodine-induced $\mathrm{O}_{3}$ loss within the marine (land mask applied and between $50^{\circ} \mathrm{N}-50^{\circ} \mathrm{S}$ ) troposphere of $\sim 540 \mathrm{Tg} \mathrm{yr}^{-1}$ is comparable to the previously reported values of Saiz-Lopez et al. (2014) when $\mathrm{I}_{2} \mathrm{O}_{X}(X=2,3,4)$ photolysis is included $\left(\sim 500 \mathrm{Tg} \mathrm{yr}^{-1}\right)$.

Figure 13 shows the relative importance of different $\mathrm{O}_{X}$ sinks in the vertical. The "classical" $\mathrm{O}_{3}$ loss routes $\left(h v+\mathrm{H}_{2} \mathrm{O}, \mathrm{HO}_{X}\right)$ dominate; however, within the boundary layer and the upper troposphere ( $350 \mathrm{hPa}>p>$ tropopause), iodine represents 33 and $26 \%$ of the total loss, respectively. The loss within the marine boundary layer $(900 \mathrm{hPa}<p)$ is comparable to the $28 \%$ reported in Prados-Roman et al. (2015a). This decreases rapidly with increasing altitude within the lower troposphere to values closer to $10 \%$, reflecting the lower of IO concentrations (see Figs. 8 and 9). In the upper troposphere, higher $\mathrm{IO}_{X}$ and $\mathrm{BrO}_{X}$ concentrations lead to increased loss of $\mathrm{O}_{3}$.

Figure 14 shows the zonal variation in the different $\mathrm{O}_{X}$ destruction terms (in terms of the $\mathrm{O}_{X}$ lifetime). It is evi-

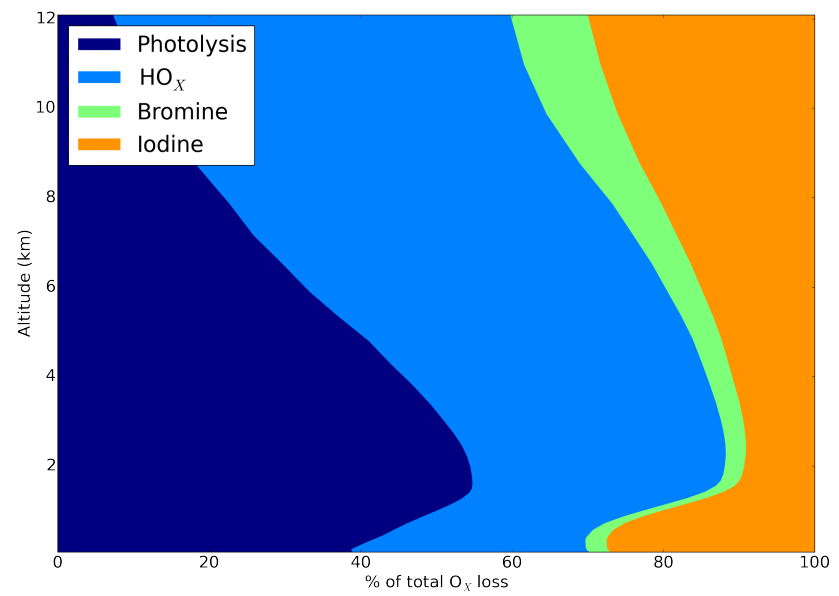

Figure 13. Vertical profile of simulated fractional global annual mean $\mathrm{O}_{X}$ loss by route in the " $\mathrm{Br}+\mathrm{I}$ " simulation. $\mathrm{O}_{X}$ definition is given in footnote 1 . Photolysis represents loss of $\mathrm{O}_{X}$ due to $\mathrm{O}_{3}$ photolysis in the presence of water vapour. $\mathrm{HO}_{X}$ loss includes routes via minor $\mathrm{NO}_{X}$ channels. The magnitude of the bromine route is probably underestimated, as discussed in Sect. 2.6. 

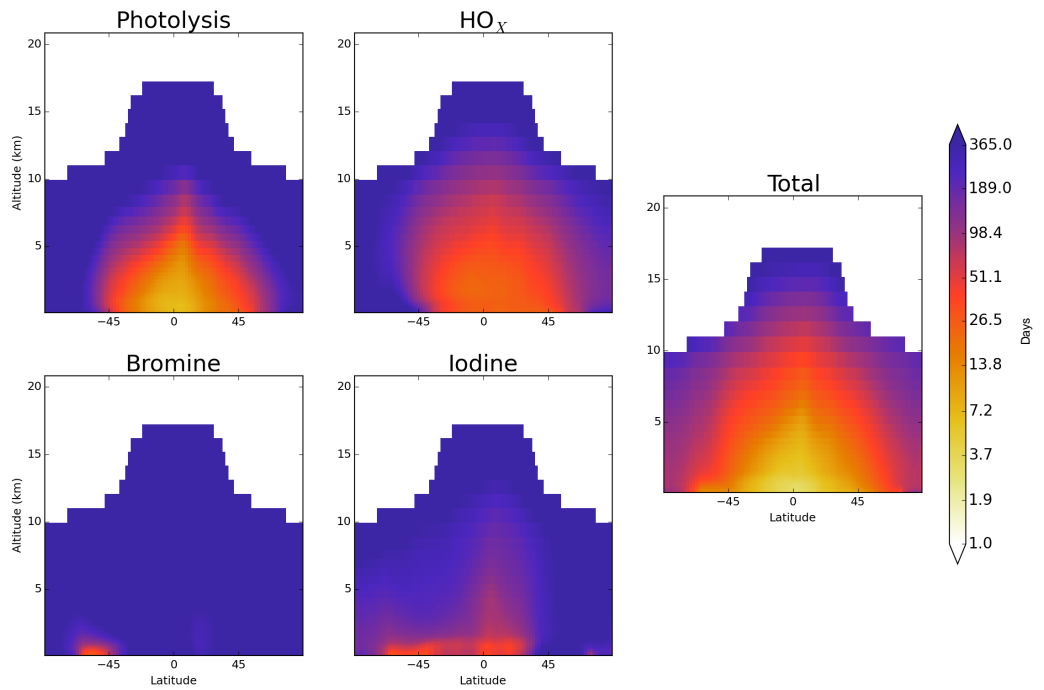

Figure 14. Global annual $\mathrm{O}_{3}$ mean zonal chemical lifetime for different $\mathrm{O}_{X}$ loss routes (Photolysis, $\mathrm{HO}_{X}$, Iodine, Bromine, and Total) in the "Br+I" simulation. Values are shown on a log scale.

dent that, in the model, iodine destruction is more spatially prevalent than bromine destruction, which is confined predominantly to the Southern Ocean. The impact of iodine is hemispherically asymmetric, reflecting the higher $\mathrm{NO}_{X}$ in the Northern Hemisphere, higher $\mathrm{BrO}$ concentrations in the southern oceans, and the larger ocean area in the Southern Hemisphere increasing emissions. Convective transport in the Tropics rapidly lifts iodine species into the free troposphere $(350 \mathrm{hPa}<p<900 \mathrm{hPa})$ where they can destroy $\mathrm{O}_{3}$.

\subsection{Impact on $\mathrm{OH}$}

Previous box model studies which investigated the impact of iodine on $\mathrm{OH}$ concentration in the Antarctic (Saiz-Lopez et al., 2008), mid-latitude coastal (Bloss et al., 2005a), tropical marine regions (Mahajan et al., 2010), and the free troposphere (Wang et al., 2015) found increases in the $\mathrm{OH}$ concentration due to $\mathrm{IO}$ enhancing conversion of $\mathrm{HO}_{2}$ to $\mathrm{OH}$. However, we find that the inclusion of iodine in the model has little impact on the global mean $\mathrm{OH}$ concentrations with it slightly increasing from 12.2 to $12.5 \times 10^{5}$ molecules $\mathrm{cm}^{-3}$ $(1.8 \%)$. This small increase is surprising given the $12 \%$ reduction in the primary source $\left(\mathrm{O}_{3}+\mathrm{H}_{2} \mathrm{O}+h v\right)$ due to lower $\mathrm{O}_{3}$ concentrations. However, this is more than compensated for by an increase in the rate of conversion of $\mathrm{HO}_{2}$ to $\mathrm{OH}$ by IO. Previous studies using constrained box models (Bloss et al., 2005a; Saiz-Lopez et al., 2008) could not consider this impact on the primary production of $\mathrm{OH}$ and it appears from our simulation that the overall impact is lower than previously thought.

\section{Combined impact of bromine and iodine}

The importance of halogen cross-over reactions $(\mathrm{BrO}+\mathrm{IO})$ for $\mathrm{O}_{3}$ loss has been previously highlighted and found to be required to replicate observed diurnal surface $\mathrm{O}_{3}$ loss in the marine boundary layer (Read et al., 2008). To explore these interactions a further two runs were performed, one simulation with iodine but without bromine ("IODINE") and one without any halogens ("NOHAL").

As shown in Table 7, the global tropospheric burdens of $\mathrm{O}_{3}$ are 390, 367 (reduction of 5.9\%), $357(8.5 \%)$ and $334 \mathrm{Tg}(14 \%)$ for the simulations without halogens ("NOHAL"), with just bromine ("BROMINE"), with just iodine ("IODINE"), and with both iodine and bromine chemistry (" $\mathrm{Br}+\mathrm{I}$ ") respectively. The sum of the changes in $\mathrm{O}_{3}$ burden for the runs considering halogens individually is slightly lower $(0.1 \%)$ than when considered simultaneously.

Figure 15 shows the combined daily surface loss rate of $\mathrm{O}_{3}$ driven by bromine and iodine (upper panel). This correlates with IO concentrations (Fig. 3) reflecting iodine's role in marine boundary layer $\mathrm{O}_{3}$ destruction. Figure 15 also shows modelled and observed fractional diurnal fractional $\mathrm{O}_{3}$ change at Cape Verde in the remote marine boundary layer (lower panel). For this comparison, observations (2006 to 2012, Sofen and Evans, 2015) and model data were first processed to average fractional diurnal change by averaging the values by hour of day, then subtracting the maximum average value of the diurnal. This fractional change was then divided by the average maximum value and multiplied by 100 to give a percentage to allow comparison between simulation runs with different $\mathrm{O}_{3}$ concentrations.

The simulation's fidelity increases significantly with the inclusion of iodine (Fig. 15) but there is little impact from bromine. Whereas modelled IO concentrations at Cape Verde 


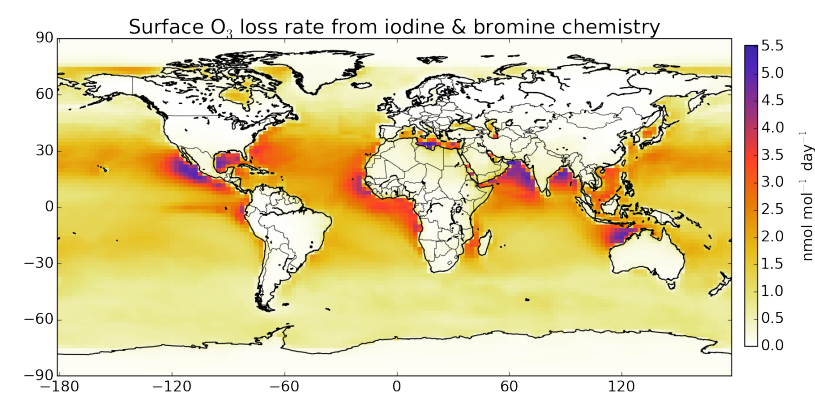

Diurnal cycle in $\mathrm{O}_{3}$ concentration at Cape Verde

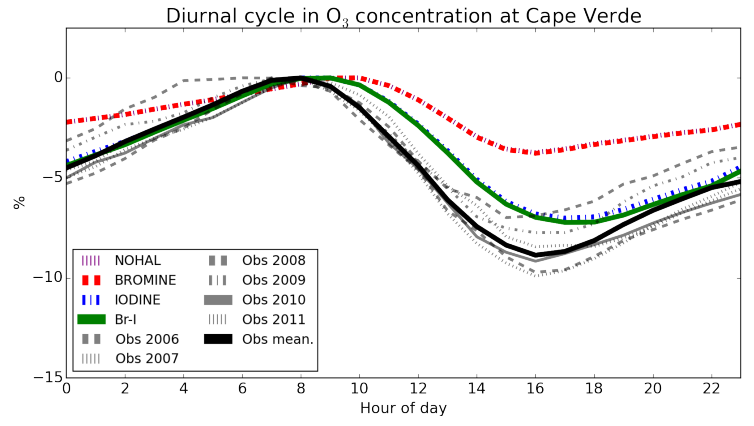

Figure 15. Global annual mean surface $\mathrm{O}_{3}$ loss $\left(\right.$ nmol mol ${ }^{-1}$ day $\left.^{-1}\right)$ in the "Br+I" simulation from both bromine and iodine (top). Comparison between modelled and observed fractional diurnal $\mathrm{O}_{3}$ cycles at the Cape Verde Observatory for "NOHAL", "BROMINE", "IODINE", and "Br+I" simulations (bottom). The calculation is described in Sect. 6. Diurnal changes are averaged over the whole data set. Lines are black, purple, red, blue, and green for mean of observations, "NOHAL", "BROMINE", "IODINE", and "Br+I" respectively. Individual years of observational data are shown in grey.

show agreement with observations (Fig. 5), BrO concentrations $\left(\sim 0.4 \mathrm{pmol} \mathrm{mol}^{-1}\right)$ are significantly lower than reported ( $\sim 2$ pmol mol${ }^{-1}$, Read et al., 2008). This underestimate of $\mathrm{BrO}$ in the model is a systemic problem (see Sect. 2.6) and so model estimates of the impact of $\mathrm{Br}$ on atmospheric composition described here are probably an underestimate.

Global mean tropospheric concentrations of $\mathrm{OH}$ are 12.80 , $12.24,13.02$, and $12.47 \times 10^{5}$ molecules $\mathrm{cm}^{-3}$ for the simulations without halogens ("NOHAL"), with just bromine ("BROMINE"), with just iodine ("IODINE"), and with both iodine and bromine chemistry (" $\mathrm{Br}+\mathrm{I}$ ") respectively. $\mathrm{OH}$ shows a differing response to bromine and iodine chemistry. As discussed in Sect. 5.3, inclusion of iodine leads to a small increase in $\mathrm{OH}$ concentrations. When solely iodine is considered, $\mathrm{OH}$ concentrations increase by $1.8 \%$ compared to when no halogens are included. Bromine chemistry leads to a reduction in $\mathrm{OH}(4.3 \%)$, as reported previously (Parrella et al., 2012), due to enhanced production by $\mathrm{HOBr}$ photolysis not compensating for a decrease in the primary $\mathrm{OH}$ source $\left(\mathrm{O}_{3}+\mathrm{H}_{2} \mathrm{O}+h v\right)$ from a reduced $\mathrm{O}_{3}$ burden. The net impact overall on inclusion of halogens is a global reduction in $\mathrm{OH}$ $(2.6 \%)$.
In our simulations, the global impact of $\mathrm{Br}$ and I chemistry are essentially additive with apparently limited impact from the cross-reactions. The global impact of iodine appears significantly larger than that of bromine - however, given that the model underestimates the concentrations of $\mathrm{Br}$ compounds this should be subject to future study.

\section{Sensitivity studies}

As discussed in the Introduction, a range of uncertainties exist in our understanding of tropospheric iodine. We perform sensitivity analysis on some of these parameters using the $4^{\circ} \times 5^{\circ}$ version of the model. We chose to analyse the sensitivity to inclusion of inorganic iodine emissions, heterogeneous loss and cycling, photolysis rates, and ocean surface iodide. Values are quoted as a percentage change from the " $\mathrm{Br}+\mathrm{I}$ " simulation described in Sects. 2-5. Figure 17 summarizes the fractional impact of these experiments on the globally averaged vertical distribution of $\mathrm{I}_{Y}, \mathrm{O}_{3}$, and vertical profile comparison of observations of IO from the TORERO aircraft campaign (Volkamer et al., 2015; Wang et al., 2015). Additional information is listed in Table A1 in Appendix A.

\subsection{Just organic iodine}

Until recently many studies solely considered organic iodine (Jones et al., 2010; Ordóñez et al., 2012) emissions. As discussed in Sect. 3.1, our simulation uses the Carpenter et al. (2013) inorganic emission parametrization as well as organic iodine emissions from Ordóñez et al. (2012). When we just consider organic iodine emissions ("Just org. I") we find that global $\mathrm{I}_{Y}$ burdens decrease (65\%), and mean surface marine boundary layer $(900 \mathrm{hPa}<p) \mathrm{IO}$ decreases $(83 \%)$. The median bias against TORERO aircraft IO observations decreases by $68 \%$ to become a negative bias of $-25 \%$. The decreased $\mathrm{I}_{Y}$ leads to the mean global $\mathrm{OH}$ decreasing by $0.64 \%$ and global tropospheric $\mathrm{O}_{3}$ increasing by $5.5 \%$.

\subsection{Heterogeneous uptake and cycling}

There are limited experimental data for the reaction probability $(\gamma)$ for iodine species on aerosol. Our base case scheme follows the literature precedent (McFiggans et al., 2000 ) and assumes a heterogeneous recycling of unity (e.g. $\mathrm{HOI} \rightarrow 1 / 2 \mathrm{I}_{2}$ ) on sea salt which is not limited by aerosol acidity. However, the acidity of aerosol may limit iodine cycling as not all sea-salt aerosols are acidic (Alexander, 2005) and other aerosols may irreversibly uptake iodine. Detail on the $\gamma$ chosen is in Appendix A (Sect. A1.2). To explore these uncertainties four simulations were run: (1) with the $\gamma$ values that lead to $I_{2}$ release doubled ("het. cycle $\times 2$ "), (2) with the $\gamma$ values halved ("het. cycle/2"), (3) with all uptake reactions leading to a net loss of iodine ("No het. cycle"), and (4) a run where sulfate aerosol leads to a sink for iodine with the same $\gamma$ values as for sea salt ("Sulfate uptake"). 
Increasing the heterogeneous cycling ("het. cycle $\times 2$ ") converts more HOI (the dominant $\mathrm{I}_{Y}$ species) into $\mathrm{I}_{2}$, thus reducing the rate of HOI deposition. The global $\mathrm{I}_{Y}$ burden increases by $6 \%$, mean surface marine boundary layer $(900 \mathrm{hPa}<p)$ IO concentration increases by $2 \%$, and the median bias with respect to the TORERO aircraft IO observations increases by 26 to $100 \%$ (Fig. 17). Decreasing the heterogeneous cycling ("het. cycle/2") has the opposite impact of roughly the same magnitude - global average $\mathrm{I}_{Y}$ burden decreases $(4.3 \%)$, average surface marine boundary layer IO decreases $(1.8 \%)$ and the median bias with respect to the TORERO aircraft IO observations decreases $(18 \%)$ to $66 \%$.

The impacts of these changes is small overall. Increased iodine cycling leads to a decrease in the tropospheric $\mathrm{O}_{3}$ burden of $0.69 \%$ and global mean $\mathrm{OH}$ increases by $0.05 \%$, whereas decreased cycling leads to the tropospheric $\mathrm{O}_{3}$ burden increasing by $0.56 \%$ and $\mathrm{OH}$ decreasing by $0.09 \%$.

By removing the release of $\mathrm{I}_{2}$ to the gas-phase following uptake of iodine ("no het. cycle") or by considering irreversible iodine loss to sulfate aerosol ("Sulfate uptake") the global $\mathrm{I}_{Y}$ burdens decrease significantly by 47 and $48 \%$, respectively. Surface marine boundary layer $(900 \mathrm{hPa}<p)$ IO concentration decreases by 48 and $22 \%$. The median bias with respect to the TORERO aircraft IO observations decreases in the case of "no het. cycle" $(84 \%)$ to $13 \%$ and decreases in "Sulfate uptake" (92\%) to $-6.7 \%$. The "Sulfate uptake" scenario shifts the median bias with the TORERO aircraft IO observations to be negative, instead of positive $\left(+80 \%\right.$ for " $\mathrm{Br}+\mathrm{I}^{\prime}$ " at $\left.4^{\circ} \times 5^{\circ}\right)$.

This large decrease in $\mathrm{I}_{Y}$ reduces the potency of iodine chemistry. The reductions in the tropospheric $\mathrm{O}_{3}$ burdens (4.1 and $4.5 \%$ for "no het. cycle" and "Sulfate uptake") are comparable to the simulation where only organic iodine sources are considered (5.5\%, "Just I Org."). Global mean $\mathrm{OH}$ decreases slightly by 0.54 and $0.87 \%$ under these two scenarios. These two sensitivity runs represent large perturbations to the iodine system, highlighting the importance and uncertainties in heterogeneous chemistry.

\subsection{Uncertainties in photolysis parameters}

Absorption cross-sections and quantum yields for iodine species are few and their temperature dependencies are not known. Notably, the absorption cross-sections for the higher iodine oxides $\left(\mathrm{I}_{2} \mathrm{O}_{2}, \mathrm{I}_{2} \mathrm{O}_{3}, \mathrm{I}_{2} \mathrm{O}_{4}\right)$ are highly uncertain (Bloss et al., 2001; Gómez Martín et al., 2005; Spietz et al., 2005) and we use the $\mathrm{INO}_{3}$ spectrum in our simulation. This uncertainty was tested in three simulations: (1) absorption crosssections were doubled (" $\mathrm{I}_{2} \mathrm{O}_{X} X$-sections $\times 2$ "), (2) tentative literature assignments of spectra were used for $\mathrm{I}_{2} \mathrm{O}_{3}$ and $\mathrm{I}_{2} \mathrm{O}_{2}$ (Bloss et al., 2001; Gómez Martín et al., 2005; Spietz et al., 2005), with $\mathrm{I}_{2} \mathrm{O}_{2}$ used for $\mathrm{I}_{2} \mathrm{O}_{4}$ (" $\mathrm{I}_{2} \mathrm{O}_{X}$ exp. $X$-sections"), (3) and finally no $\mathrm{I}_{2} \mathrm{O}_{X}$ photolysis at all was considered ("No $\mathrm{I}_{2} \mathrm{O}_{X}$ photolysis").

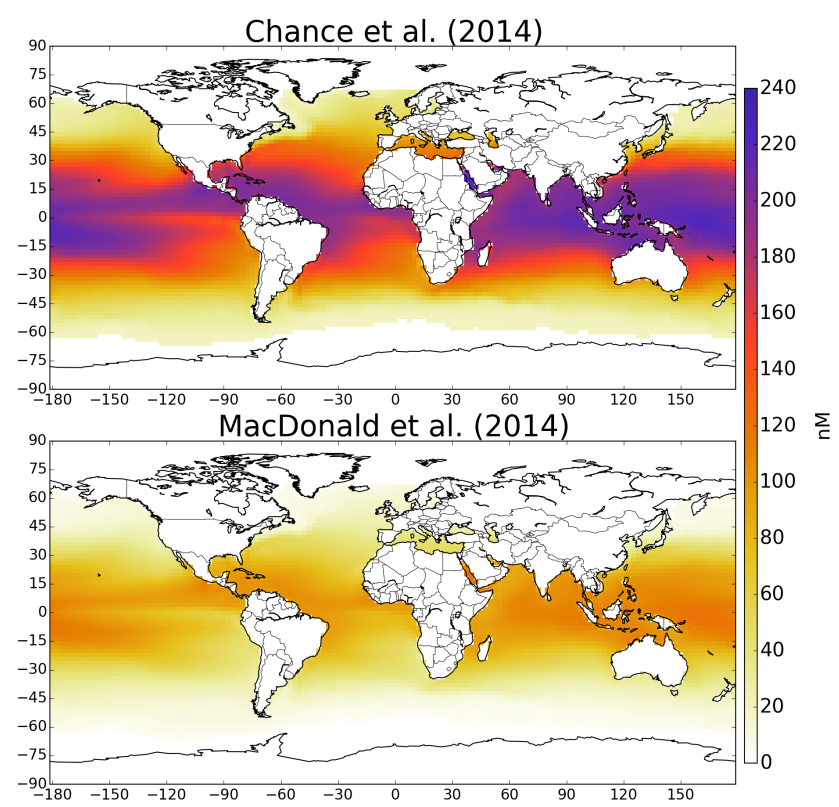

Figure 16. Calculated annual mean ocean surface iodide concentrations $\left(\mathrm{I}^{-}\right)$in $\mathrm{nM}$. Values are calculated from the highest correlation relationship (square) presented in Table 2 of Chance et al. (2014) (top panel) and from the Arrhenius relationship from Eq. (1) in MacDonald et al. (2014) (bottom panel). The Chance et al. (2014) parametrization is used as the standard in the work with the MacDonald et al. (2014) used as the "Ocean iodide" sensitivity simulation in Sect. 7.

Sensitivity runs " $\mathrm{I}_{2} \mathrm{O}_{X} X$-sections $\times 2$ " and " $\mathrm{I}_{2} \mathrm{O}_{X}$ exp. $\mathrm{X}$ sections" increase photolysis rates, therefore resulting in an increase in the $\mathrm{I}_{Y}$ lifetime of 5.3 and $8.3 \%$ and the $\mathrm{I}_{Y}$ burdens by 3.1 and $4.8 \%$ respectively. The average surface marine boundary layer $(900 \mathrm{hPa}<p)$ IO concentration responds by increasing by 4.3 and $6.7 \%$ for " $\mathrm{I}_{2} \mathrm{O}_{X} \mathrm{X}$-sections $\times 2$ " and " $\mathrm{I}_{2} \mathrm{O}_{X}$ exp. X-sections" respectively. Both these simulations increase median bias with TORERO aircraft IO observations by 4.8 to $84 \%$ and 7.6 to $86 \%$, respectively. The impacts on $\mathrm{O}_{3}$ burden are small with a decrease of 0.4 and $0.6 \%$ for " $\mathrm{I}_{2} \mathrm{O}_{X}$ X-sections $\times 2$ " and " $\mathrm{I}_{2} \mathrm{O}_{X}$ exp. X-sections" respectively. Global mean $\mathrm{OH}$ concentrations increase by 0.05 and $0.09 \%$ respectively.

The removal of $\mathrm{I}_{2} \mathrm{O}_{X}(X=2,3,4)$ photolysis reduces the global tropospheric $\mathrm{I}_{Y}$ burden $(35 \%)$, reduces surface marine boundary layer $(900 \mathrm{hPa}<p)$ IO $(40 \%)$, increases tropospheric $\mathrm{O}_{3}$ burden $(5.1 \%)$ and decreases global mean $\mathrm{OH}$ $(0.9 \%)$ with respect to "Br+I". The median bias with respect to the TORERO aircraft IO observations becomes negative and decreases by 81 to $-16 \%$, illustrating a large change in the simulated IO profile by removing the $\mathrm{I}_{2} \mathrm{O}_{X}$ photolysis (Fig. 17). This was also noted by Prados-Roman et al. (2015b) with respect to surface observations.

Our "No $\mathrm{I}_{2} \mathrm{O}_{X}$ photolysis" simulation is akin to the "base" simulation of Saiz-Lopez et al. (2014). This was presented 

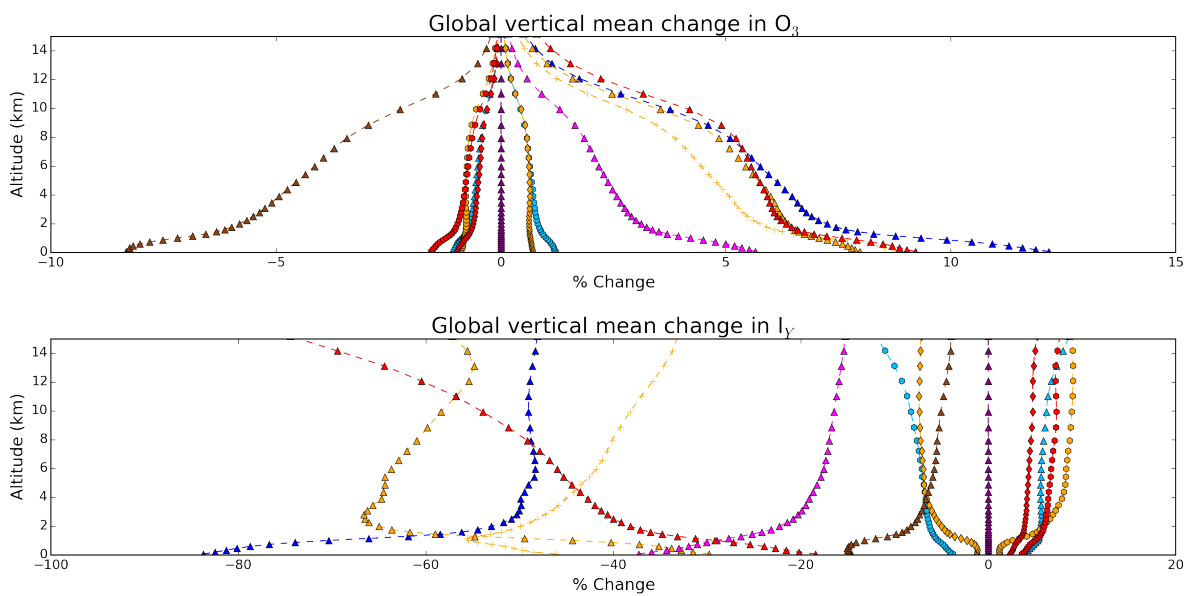

Observed vertical profile of IO on TORERO flightpaths against model

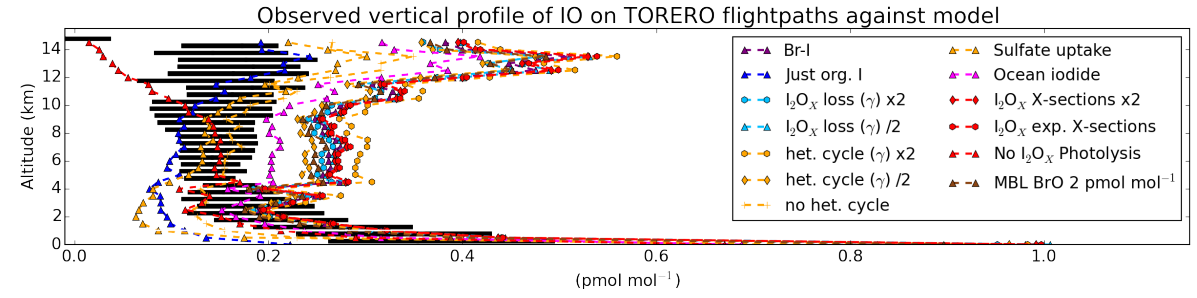

Figure 17. Sensitivity impacts. Upper and middle panels show global mean vertical percentage changes in concentrations of $\mathrm{O}_{3}$ and $\mathrm{I}_{Y}$. Lower panel gives vertically averaged iodine oxide (IO) mixing ratios ( $\mathrm{pmol} \mathrm{mol}^{-1}$ ) calculated along the TORERO aircraft (Volkamer et al., 2015; Wang et al., 2015) flight paths. The legend (bottom) is shared by all plots. The boxplot of IO observations (black) represents the quartiles of the data, with the median shown within the box.

as a lower bound for iodine chemistry. Their " $\mathrm{JI}_{X} \mathrm{O}_{Y}$ " simulation, is akin to our "Br+I". Saiz-Lopez et al. (2014) find a decrease in marine tropospheric $\mathrm{O}_{3}$ column burden of 3.0 and $6.1 \%$ compared to a simulation with no iodine chemistry for their "base" and " $\mathrm{JI}_{X} \mathrm{O}_{Y}$ " simulations respectively. Considering the same domain, our comparable simulations show values of 4.0 to $8.7 \%$.

\subsection{Marine boundary layer BrO concentration}

As discussed in the Introduction and Sect. 6, bromine and iodine chemistry are potentially coupled. GEOS-Chem underestimates BrO (Parrella et al., 2012), with for example, our simulation underestimating the $\mathrm{BrO}$ concentrations at Cape Verde (Read et al., 2008) $\left(\sim 2 \mathrm{pmol} \mathrm{mol}^{-1}\right)$ by a factor of around 5.

To test the sensitivity of the model to $\mathrm{BrO}$ concentrations, a simulation with $\mathrm{BrO}$ concentration fixed at $2 \mathrm{pmol} \mathrm{mol}^{-1}$ in the daytime marine boundary layer was run ("MBL $\mathrm{BrO}$ $2 \mathrm{pmol} \mathrm{mol}^{-1}$ "). Increased BrO leads to increased OIO concentrations $(\mathrm{BrO}+\mathrm{IO} \rightarrow \mathrm{OIO}+\mathrm{Br})$, which leads to increased higher oxide production which in turn increases $\mathrm{I}_{Y}$ loss and decreases $I_{Y}$ burden (10\%). The median bias in vertical comparisons with TORERO aircraft IO observations decreases by 12 to $71 \%$. Although the overall tropospheric $\mathrm{O}_{3}$ burden decreases by $3.7 \%$, the average $\mathrm{O}_{3}$ change at the surface is larger and shows a decrease of $88 \%$ (Fig. 17) which is the largest decrease in $\mathrm{O}_{3}$ found within these sensitivity simulations.

\subsection{Ocean surface iodide $\left(\mathrm{I}^{-}\right)$concentration}

Chance et al. (2014) compiled the available ocean surface iodide $\left(\mathrm{I}^{-}\right)$observations and investigated correlations with various environmental parameters. They found that ocean surface iodide correlated most strongly with the square of sea surface temperature, as used in this work. However, MacDonald et al. (2014), using a sub-set of the Chance et al. (2014) data, found that an Arrhenius parametrization gave best agreement. Figure 16 shows annual averaged ocean surface iodide generated from both parametrizations. The sea surface temperatures are taken from the annual average GEOS field used in GEOS-Chem. The area weighted mean concentrations are 37.6 and $80.8 \mathrm{nM}$ for MacDonald et al. (2014) and Chance et al. (2014), respectively. Both approaches reproduce the latitudinal gradient observed in Fig. 1 of Chance et al. (2014); however, large differences are apparent in magnitude. The data set reported in Chance et al. (2014) has a median value of $77 \mathrm{nM}$ and interquartile range of $28-140 \mathrm{nM}$.

Inclusion of the MacDonald et al. (2014) iodide parametrization ("Ocean Iodide") reduces the inorganic iodine flux by $51 \%$ to $1.9 \mathrm{Tg}$, which in turn decreases the global tropospheric iodine $\mathrm{I}_{Y}$ burden $(23 \%)$ and surface IO 
concentrations $(34 \%)$. The median bias in comparison with TORERO vertical profiles decreases by 47 to $42 \%$. Tropospheric $\mathrm{O}_{3}$ burden increases by $2.1 \%$ and global mean $\mathrm{OH}$ increases by $0.17 \%$ with respect to " $\mathrm{Br}+\mathrm{I}$ ".

\subsection{Higher-oxide lifetime}

Within the model we have considered the uptake of the $\mathrm{I}_{2} \mathrm{O}_{X}$ $(X=2,3,4)$ to aerosol as an irreversible loss of iodine, with the same reactive probability $(\gamma)$ as $\mathrm{INO}_{2}(0.02)$. We assess our sensitivity to this assumption by running simulations doubling (" $\mathrm{I}_{2} \mathrm{O}_{X}(\gamma) \times 2$ ") and halving this value (" $\mathrm{I}_{2} \mathrm{O}_{X}$ $(\gamma) / 2 ")$.

The effect of doubling $\gamma$ leads to decreasing global tropospheric $\mathrm{I}_{Y}$ burden $(5.1 \%)$, decreasing surface marine boundary layer $(900 \mathrm{hPa}<p)$ IO $(4.6 \%)$, and decreases the median bias in vertical comparisons with TORERO aircraft IO $(6.9 \%)$ to $75 \%$. This leads to a slightly increased global tropospheric $\mathrm{O}_{3}$ burden $(0.54 \%)$, and marginally decrease in global mean $\mathrm{OH}(0.08 \%)$. The effect of halving $\gamma$ is essentially symmetrical, with an increased global tropospheric $\mathrm{I}_{Y}$ burden $(4.3 \%)$, increased surface marine boundary layer $(900 \mathrm{hPa}<p)$ IO concentration $(4.3 \%)$, and an increased median bias in vertical comparisons with TORERO aircraft IO by 4.4 to $84 \%$. This leads to slightly decreased global tropospheric $\mathrm{O}_{3}$ burden $(0.44 \%)$, and marginal increase in $\mathrm{OH}$ $(0.05 \%)$.

\subsection{Summary of sensitivity simulations}

Uncertainties in the atmospheric chemistry of iodine lead to some significant uncertainties on iodine's impact on atmospheric composition. Further laboratory studies on the photolytic properties of high oxides would reduce uncertainty, as would a more detailed understanding of the rates of heterogenous cycling on a range of aerosols. The interplay between bromine and iodine chemistry is also potentially significant for the oxidant budgets. Given the inorganic iodine emissions' role as the largest source of iodine into the atmosphere, improved constraints on the concentration of oceanic iodide would also reduce uncertainties. It is clear that we do not have a complete understanding of iodine chemistry in the atmosphere and further laboratory and field observations are necessary to provide a stronger constraint.

\section{Conclusions}

We have implemented a representation of the tropospheric chemistry of iodine into the GEOS-Chem model and compared it against a range of observational data sets. We estimate a global emission of $3.8 \mathrm{Tg} \mathrm{yr}^{-1}$ of iodine, which is consistent with previous work. We find this dominated by the inorganic ocean source (84\%), and the majority (91\%) of deposition is back to the oceans.

Comparisons with the limited IO observational data set shows that the model is within a factor of 2 of the observations on average. Iodine reduces the global tropospheric $\mathrm{O}_{3}$ burden by $\sim 9 \%$. Global mean $\mathrm{OH}$ concentrations are increased $(1.8 \%)$ by the presence of iodine due to the reduction in the $\mathrm{O}_{3}+\mathrm{H}_{2} \mathrm{O}$ primary source being compensated for by an increased conversion of $\mathrm{HO}_{2}$ into $\mathrm{OH}$ via the photolysis of HOI. Both changes involve HOI production and destruction cycles.

Our understanding of iodine chemistry is hampered by limited laboratory studies of both its gas and aerosol phase chemistry, by limited field measurements of atmospheric iodine compounds, and poor understanding of ocean surface iodide and its chemistry. Impacts on $\mathrm{O}_{3}$ and $\mathrm{OH}$ are sensitive to the uncertainty of ocean iodine emissions, the parametrization of iodine recycling in aerosol, to the photolysis parameters for the higher oxides, and to the assumed $\mathrm{Br}$ chemistry. Given its role as the largest component of atmospheric iodine, and its central role in both $\mathrm{O}_{3}$ destruction and $\mathrm{HO}_{2}$ to IO cycling, a priority should be given to instrumentation to measure HOI. 


\section{Appendix A}

\section{A1 Additional details on sensitivity runs}

\section{A1.1 Details of reactions within scheme, but not present within IUPAC/JPL}

The field of iodine chemistry is still young, and some reactions that are used within box model/global studies are not in the IUPAC/JPL compilations due to uncertainties in the laboratory studies or for other reasons. Different choices have been made regarding reactions included in previous box model (Bloss et al., 2010; Mahajan et al., 2009; Read et al., 2008; Saiz-Lopez et al., 2008; Sommariva et al., 2012) and global model studies (Breider, 2010; Ordóñez et al., 2012; Saiz-Lopez et al., 2012b, 2014). The following reactions have been included within our simulation's chemistry scheme (Tables 3 and 4) although they are not in the IUPAC/JPL compilations.

$\mathrm{HOI}+\mathrm{OH} \rightarrow \mathrm{IO}+\mathrm{H}_{2} \mathrm{O}$

Uncertainties exist over product channels for this reaction (Sommariva et al., 2012). In our study we assume the products are $\mathrm{IO}$ and $\mathrm{H}_{2} \mathrm{O}$ based on laboratory experiments (Riffault et al., 2005) and previous box model analysis (Sommariva et al., 2012).

$\mathrm{INO}_{3}+\mathrm{I} \rightarrow \mathrm{I}_{2}+\mathrm{NO}_{3}$

This reaction's rate is based on a single theoretical study (Kaltsoyannis and Plane, 2008). The impact of inclusion within a box model was found to be minimal, except in high iodine and $\mathrm{NO}_{X}$ conditions (Sommariva et al., 2012).

$\mathrm{OIO}+\mathrm{OIO} \rightarrow \mathrm{I}_{2} \mathrm{O}_{4}$

This reaction rate is from a single experimental study (Gómez Martín et al., 2007), which yielded a lower limit of $1.2 \pm 0.3 \times 10^{-10} \mathrm{~cm}^{3}$ molecules ${ }^{-1} \mathrm{~s}^{-1}$. This reaction is included in this work, along with the reverse reaction (Reaction $\mathrm{M} 24, \mathrm{I}_{2} \mathrm{O}_{4} \rightarrow$ 2OIO).

$\mathrm{INO}_{3} \stackrel{\mathrm{M}}{\rightarrow} \mathrm{IO}+\mathrm{NO}_{2}$

The reaction is included in the IUPAC (Atkinson et al., 2007) without direct experiment observation. No recommendation is given in the recent JPL compilation (Sander et al., 2011). The $\mathrm{INO}_{3}$ thermal stability used by studies has led to a significant range between reaction rates $(298 \mathrm{~K})$ from $1.08 \times$ $10^{-2}$ (Read et al., 2008) to $2.51 \times 10^{-5} \mathrm{~cm}^{3}$ molecules ${ }^{-1} \mathrm{~s}^{-1}$ (Sommariva et al., 2012). The latter use the most recent theoretical study (Kaltsoyannis and Plane, 2008), which we also use here. The forward reaction (Reaction M25) has been included ubiquitously in iodine modelling work; and the reverse reaction (Reaction M26) is employed in the majority of, but not all studies (Ordóñez et al., 2012). Both reactions are included in this work.

$\mathrm{IO}+\mathrm{OIO} \stackrel{\mathrm{M}}{\rightarrow} \mathrm{I}_{2} \mathrm{O}_{3}$

A single experimental study (Gómez Martín et al., 2007) gives a upper limit and lower rate limit of $1.5 \times 10^{-10}$ and $1.5 \times 10^{-11} \mathrm{~cm}^{3}$ molecules ${ }^{-1} \mathrm{~s}^{-1}$, respectively. We use the higher value in this work as in others studies (Saiz-Lopez et al., 2008; Sommariva et al., 2012).

$\mathrm{I}_{2} \mathrm{O}_{2} \stackrel{\mathrm{M}}{\rightarrow} \mathrm{IO}+\mathrm{IO}$

$\mathrm{I}_{2} \mathrm{O}_{2} \stackrel{\mathrm{M}}{\rightarrow} \mathrm{OIO}+\mathrm{I}$

These reactions have been studied solely theoretically (Kaltsoyannis and Plane, 2008). A temperature-dependent rate was calculated theoretically (Ordóñez et al., 2012) which is used in our work.

$\mathrm{I}_{2} \mathrm{O}_{4} \stackrel{\mathrm{M}}{\rightarrow} 2 \mathrm{OIO}$

The rate is calculated from the value for binding energy of the dimer (Kaltsoyannis and Plane, 2008). As we have included Reaction $\mathrm{M} 17\left(\mathrm{OIO}+\mathrm{OIO} \rightarrow \mathrm{I}_{2} \mathrm{O}_{4}\right)$, we also include the reverse reaction (M24) in our work at the Kaltsoyannis and Plane (2008) rate.

\section{A1.2 Detail of reactive uptake coefficients $(\gamma)$ used for heterogeneous reactions}

As described in Sect. 3.1, we stoichiometrically emit $\mathrm{I}_{2}$ following the uptake of species that hydrolyse to $\mathrm{HOI}\left(\mathrm{INO}_{2}\right.$, $\mathrm{INO}_{3}, \mathrm{HOI}$ ). We assume this to avoid double counting of $\mathrm{Br}$ release already included within the model as described by Parrella et al. (2012). Lack of, or limited experimental data reduces certainty on heterogeneous processing of halogens. The reactive uptake coefficients $(\gamma)$ used in this study are experimentally constrained wherever possible or follow previously estimated values in the literature as described below.

The JPL compilation notes a single experimental study of $\mathrm{HOI}$ uptake on $\mathrm{H}_{2} \mathrm{SO}_{4}$, yielding mass accommodation coefficients $(\alpha)$ in the range 0.02 to 0.07 (Sander et al., 2011). Another two studies on ice and salt are reported in JPL with lower limits of 0.0022 and 0.01 respectively (Sander et al., 2011). IUPAC evaluates two experimental studies which "concur (the) uptake coefficient is large", but no recommendation is given due to possible uncertainties in reversibility (Crowley et al., 2010). The $\gamma$ values used in the literature range between 0.01 (Mahajan et al., 2009; Breider, 2010) and 0.5 (Saiz-Lopez et al., 2007). The higher end of this range originates from an investigation of the sensitivity to this parameter by Saiz-Lopez et al. (2007) for which the base case was set as 0.02 . A $\gamma$ value of 0.01 is used within our work.

For $\mathrm{INO}_{2}$ and $\mathrm{INO}_{3}$ no experiment work is available on the uptake and values have previously been estimated by analogy with measured equivalent bromine species. For $\mathrm{INO}_{3}$ a $\gamma$ 
value of 0.01 has been frequently used based on estimations (Mahajan et al., 2009; Ordóñez et al., 2012), but values have been used up to 0.2 (Bloss et al., 2010). For $\mathrm{INO}_{2} \gamma$ values of 0.01 (Mahajan et al., 2009) or 0.02 (Ordóñez et al., 2012; Saiz-Lopez et al., 2007) have often been used, but $\gamma$ values up to 0.1 have also been used (Bloss et al., 2010). In this work $\gamma$ values of 0.01 and 0.02 are used for $\mathrm{INO}_{3}$ and $\mathrm{INO}_{2}$ respectively.

The IUPAC compilation includes a recommendation for HI uptake $\gamma$ on ice of 0.2 (Crowley et al., 2010), based on three experimental studies. A $\gamma$ value of 0.1 though has most often been used in modelling studies (Breider, 2010; Mahajan et al., 2009; Saiz-Lopez et al., 2008) and is used in this work.
For $\mathrm{I}_{2} \mathrm{O}_{X}(X=2,3,4)$ no experimental data are available for reactive uptake coefficients. The uptake has been discussed in the literature, including a box model study which tested sensitivity around a base value of 0.02 (Saiz-Lopez et al., 2008). The $\gamma$ value for $\mathrm{I}_{2} \mathrm{O}_{X}$ was set at 0.02 by with analogy $\mathrm{INO}_{2}$. This value is highly uncertain and values up to 1 have been used for gamma in modelling studies (Bloss et al., 2010). A value of 0.02 is used within this work. 
Table A1. Effects of sensitivity runs on relevant variables. Values are shown as percentage change from the simulation with both iodine and bromine chemistry ("Br+I") in the troposphere as global means unless otherwise stated. $\mathrm{MBL}=$ Marine Boundary Layer $(900 \mathrm{hPa}<p), \mathrm{O}_{X}$ is defined as in footnote $1 . \mathrm{CH}_{4}$ lifetime is calculated globally in the troposphere with respect to loss by reaction with $\mathrm{OH}$.

\begin{tabular}{|c|c|c|c|c|c|c|c|}
\hline & $\begin{array}{r}\text { Mean IO MBL } \\
\text { surface } \\
\text { concentration }\end{array}$ & $\begin{array}{l}\text { Chem. } \mathrm{O}_{X} \\
\text { loss }\left(\mathrm{LO}_{X}\right)\end{array}$ & \multicolumn{2}{|c|}{$\begin{array}{r}\text { Chem. } \mathrm{O}_{X} \\
\text { prod. }\left(\mathrm{PO}_{X}\right)\end{array}$} & \multirow{2}{*}{$\begin{array}{r}\mathrm{PO}_{X} \\
-\mathrm{LO}_{X} \\
40.91\end{array}$} & $\begin{array}{r}\mathrm{O}_{3} \\
\text { burden }\end{array}$ & $\begin{array}{r}\mathrm{O}_{3} \\
\text { deposition }\end{array}$ \\
\hline NOHAL & -100.00 & 2.34 & & -0.75 & & 15.99 & 17.75 \\
\hline BROMINE & -100.00 & -1.79 & & -3.90 & 24.50 & 9.12 & 10.42 \\
\hline IODINE & 9.63 & 3.87 & & 2.89 & 16.16 & 6.90 & 6.87 \\
\hline $\mathrm{Br}+\mathrm{I}$ & 0.00 & 0.00 & & 0.00 & 0.00 & 0.00 & 0.00 \\
\hline Just org. I & -83.45 & -1.64 & & -3.11 & 17.69 & 5.53 & 7.19 \\
\hline $\mathrm{I}_{2} \mathrm{O}_{X} \operatorname{loss}(\gamma) \times 2$ & -4.26 & -0.15 & & -0.28 & 1.61 & 0.54 & 0.59 \\
\hline $\mathrm{I}_{2} \mathrm{O}_{X} \operatorname{loss}(\gamma) / 2$ & 3.93 & 0.13 & & 0.24 & -1.34 & -0.44 & -0.52 \\
\hline Het. cycle $(\gamma) \times 2$ & 2.21 & 0.04 & & 0.16 & -1.61 & -0.69 & -0.56 \\
\hline Het. cycle $(\gamma) / 2$ & -1.84 & -0.06 & & -0.14 & 1.07 & 0.56 & 0.45 \\
\hline No het. cycle & -48.03 & -1.15 & & -2.20 & 12.60 & 4.09 & 5.23 \\
\hline Sulfate uptake & -22.49 & -1.25 & & -2.26 & 12.06 & 4.54 & 4.94 \\
\hline Ocean iodide & -34.28 & -0.66 & & -1.26 & 7.24 & 2.06 & 3.01 \\
\hline $\mathrm{I}_{2} \mathrm{O}_{X} X$-sections $\times 2$ & 4.30 & 0.11 & & 0.22 & -1.34 & -0.40 & -0.47 \\
\hline $\mathrm{I}_{2} \mathrm{O}_{X}$ exp. $X$-sections & 6.73 & 0.19 & & 0.35 & -1.88 & -0.60 & -0.73 \\
\hline No $\mathrm{I}_{2} \mathrm{O}_{X}$ photolysis & -39.35 & -1.10 & & -2.12 & 12.33 & 5.05 & 4.86 \\
\hline \multirow[t]{2}{*}{ MBL BrO $2 \mathrm{pmol} \mathrm{mol}^{-1}$} & -6.78 & -3.59 & & -2.71 & -15.28 & -3.73 & -6.03 \\
\hline & $\begin{array}{r}\mathrm{OH} \text { mean } \\
\text { concentration }\end{array}$ & $\begin{array}{r}\mathrm{HO}_{2} \text { mean } \\
\text { concentration }\end{array}$ & $\begin{array}{l}\mathrm{HO}_{2} \\
/ \mathrm{OH}\end{array}$ & $\begin{array}{r}\mathrm{I}_{Y} \\
\text { lifetime }\end{array}$ & $\begin{array}{r}\mathrm{IO}_{X} \\
\text { lifetime }\end{array}$ & $\begin{array}{r}\mathrm{I}_{Y} \\
\text { burden }\end{array}$ & $\begin{array}{r}\mathrm{CH}_{4} \\
\text { lifetime }\end{array}$ \\
\hline NOHAL & 2.49 & 8.44 & 5.81 & -100.00 & 105.16 & -100.00 & -3.73 \\
\hline BROMINE & -1.65 & 5.72 & 7.50 & -100.00 & 89.64 & -100.00 & 0.80 \\
\hline IODINE & 4.30 & 2.31 & -1.91 & -1.31 & -1.82 & 6.96 & -4.67 \\
\hline $\mathrm{Br}+\mathrm{I}$ & 0.00 & 0.00 & 0.00 & 0.00 & 0.00 & 0.00 & 0.00 \\
\hline Just org. I & -0.64 & 3.53 & 4.19 & 123.92 & 16.09 & -64.26 & 0.21 \\
\hline $\mathrm{I}_{2} \mathrm{O}_{X}$ loss $(\gamma) \times 2$ & -0.08 & 0.27 & 0.36 & -8.38 & -0.93 & -5.08 & 0.03 \\
\hline $\mathrm{I}_{2} \mathrm{O}_{X} \operatorname{loss}(\gamma) / 2$ & 0.05 & -0.22 & -0.27 & 8.00 & 0.55 & 4.27 & -0.01 \\
\hline Het. cycle $(\gamma) \times 2$ & 0.09 & -0.39 & -0.49 & 4.61 & 1.13 & 5.98 & 0.00 \\
\hline Het. cycle $(\gamma) / 2$ & -0.09 & 0.32 & 0.41 & -3.89 & -0.96 & -5.04 & 0.02 \\
\hline No het. cycle & -0.47 & 2.58 & 3.07 & -61.18 & 5.38 & -46.69 & 0.15 \\
\hline Sulfate uptake & -0.87 & 2.70 & 3.60 & -59.60 & 0.49 & -48.49 & 0.52 \\
\hline Ocean iodide & -0.17 & 1.22 & 1.39 & 16.90 & 2.77 & -23.42 & 0.01 \\
\hline $\mathrm{I}_{2} \mathrm{O}_{X} X$-sections $\times 2$ & 0.05 & -0.20 & -0.25 & 5.26 & 0.61 & 3.10 & -0.01 \\
\hline $\mathrm{I}_{2} \mathrm{O}_{X}$ exp. $X$-sections & 0.08 & -0.31 & -0.39 & 8.31 & 0.84 & 4.81 & -0.01 \\
\hline $\mathrm{No}_{2} \mathrm{O}_{X}$ photolysis & -0.90 & 2.54 & 3.48 & -46.41 & -17.68 & -34.58 & 0.32 \\
\hline MBL BrO $2 \mathrm{pmol} \mathrm{mol}^{-1}$ & -3.31 & -1.44 & 1.93 & -3.72 & 3.33 & -10.07 & 4.17 \\
\hline
\end{tabular}


Acknowledgements. This work was funded by NERC quota studentship NE/K500987/1 with support from the NERC BACCHUS and CAST projects NE/L01291X/1, NE/J006165/1.

R. Volkamer acknowledges funding from US National Science Foundation CAREER award ATM-0847793, AGS-1104104, and AGS-1452317. The involvement of the NSF-sponsored Lower Atmospheric Observing Facilities, managed and operated by the National Center for Atmospheric Research (NCAR) Earth Observing Laboratory (EOL), is acknowledged.

T. Sherwen would like to acknowledge constructive comments from and conversations with all coauthors as well as R. Chance and J. Schmidt.

Edited by: M. Uematsu

\section{References}

Ainsworth, E. A., Yendrek, C. R., Sitch, S., Collins, W. J., and Emberson, L. D.: The effects of tropospheric ozone on net primary productivity and implications for climate change, Annu. Rev. Plant Bio., 63, 637-661, doi:10.1146/annurev-arplant-042110103829, 2012.

Alexander, B.: Sulfate formation in sea-salt aerosols: Constraints from oxygen isotopes, J. Geophys. Res., 110, D10307, doi:10.1029/2004JD005659, 2005.

Amos, H. M., Jacob, D. J., Holmes, C. D., Fisher, J. A., Wang, Q., Yantosca, R. M., Corbitt, E. S., Galarneau, E., Rutter, A. P., Gustin, M. S., Steffen, A., Schauer, J. J., Graydon, J. A., Louis, V. L. St., Talbot, R. W., Edgerton, E. S., Zhang, Y., and Sunderland, E. M.: Gas-particle partitioning of atmospheric $\mathrm{Hg}$ (II) and its effect on global mercury deposition, Atmos. Chem. Phys., 12, 591-603, doi:10.5194/acp-12-591-2012, 2012.

Andrews, S. J., Jones, C. E., and Carpenter, L. J.: Aircraft measurements of very short-lived halocarbons over the tropical Atlantic Ocean, Geophys. Res. Lett., 40, 1005-1010, doi:10.1002/grl.50141, 2013.

Andrews, S. J., Hackenberg, S. C., and Carpenter, L. J.: Technical Note: A fully automated purge and trap GC-MS system for quantification of volatile organic compound (VOC) fluxes between the ocean and atmosphere, Ocean Sci., 11, 313-321, doi:10.5194/os11-313-2015, 2015.

Atkinson, R., Baulch, D. L., Cox, R. A., Crowley, J. N., Hampson, R. F., Hynes, R. G., Jenkin, M. E., Rossi, M. J., and Troe, J.: Evaluated kinetic and photochemical data for atmospheric chemistry: Volume III - gas phase reactions of inorganic halogens, Atmos. Chem. Phys., 7, 981-1191, doi:10.5194/acp-7-981-2007, 2007.

Atkinson, R., Baulch, D. L., Cox, R. A., Crowley, J. N., Hampson, R. F., Hynes, R. G., Jenkin, M. E., Rossi, M. J., Troe, J., and Wallington, T. J.: Evaluated kinetic and photochemical data for atmospheric chemistry: Volume IV - gas phase reactions of organic halogen species, J. Phys. Chem. Ref. Data, 8, 4141-4496, 2008.

Bedjanian, Y., Le Bras, G., and Poulet, G.: Kinetic study of the Br+ $\mathrm{IO}, \mathrm{I}+\mathrm{BrO}$ and $\mathrm{Br}+\mathrm{I} 2$ reactions. Heat of formation of the $\mathrm{BrO}$ radical, Chem. Phys. Lett., 266, 233-238, doi:10.1016/S00092614(97)01530-3, 1997.

Bell, N., Hsu, L., Jacob, D. J., Schultz, M. G., Blake, D. R., Butler, J. H., King, D. B., Lobert, J. M., and Maier-Reimer, E.:
Methyl iodide: atmospheric budget and use as a tracer of marine convection in global models, J. Geophys. Res.-Atmos., 107, ACH8.1-ACH8.12, doi:10.1029/2001jd001151, 2002.

Bell, R. P.: The Proton in Chemistry, 2nd Edn., Cornell University Press, 1973.

Bian, H. S. and Prather, M. J.: Fast-J2: accurate simulation of stratospheric photolysis in global chemical models, J. Atmos. Chem., 41, 281-296, doi:10.1023/a:1014980619462, 2002.

Bloss, W. J., Rowley, D. M., Cox, R. A., and Jones, R. L.: Kinetics and products of the IO self-reaction, J. Phys. Chem. A, 105, 7840-7854, doi:10.1021/jp0044936, 2001.

Bloss, W. J., Lee, J. D., Johnson, G. P., Sommariva, R., Heard, D. E., Saiz-Lopez, A., Plane, J. M. C., McFiggans, G., Coe, H., Flynn, M., Williams, P., Rickard, A. R., Fleming, L. Z.: Impact of halogen monoxide chemistry upon boundary layer $\mathrm{OH}$ and $\mathrm{HO}_{2}$ concentrations at a coastal site, Geophys. Res. Lett., 32, L06814, doi:10.1029/2004GL022084, 2005a.

Bloss, W. J., Evans, M. J., Lee, J. D., Sommariva, R., Heard, D. E., and Pilling, M. J.: The oxidative capacity of the troposphere: coupling of field measurements of $\mathrm{OH}$ and a global chemistry transport model, Faraday Discuss., 130, 425-436, doi:10.1039/b419090d, 2005b.

Bloss, W. J., Camredon, M., Lee, J. D., Heard, D. E., Plane, J. M. C., Saiz-Lopez, A., Bauguitte, S. J.-B., Salmon, R. A., and Jones, A. E.: Coupling of $\mathrm{HO}_{x}, \mathrm{NO}_{x}$ and halogen chemistry in the antarctic boundary layer, Atmos. Chem. Phys., 10, 1018710209, doi:10.5194/acp-10-10187-2010, 2010.

Braban, C. F., Adams, J. W., Rodriguez, D., Cox, R. A., Crowley, J. N., and Schuster, G.: Heterogeneous reactions of HOI, $\mathrm{ICl}$ and $\mathrm{IBr}$ on sea salt and sea salt proxies, Phys. Chem. Chem. Phys., 9, 3136-3148, doi:10.1039/b700829e, 2007.

Breider, T. J.: Coupled Halogen-Sulfur-Aerosol Modelling in a 3D Chemical Transport Model, PhD thesis, University of Leeds, Leeds, 2010

Butz, A., Bösch, H., Camy-Peyret, C., Chipperfield, M. P., Dorf, M., Kreycy, S., Kritten, L., Prados-Román, C., Schwärzle, J., and Pfeilsticker, K.: Constraints on inorganic gaseous iodine in the tropical upper troposphere and stratosphere inferred from balloon-borne solar occultation observations, Atmos. Chem. Phys., 9, 7229-7242, doi:10.5194/acp-9-7229-2009, 2009.

Carpenter, L. J., MacDonald, S. M., Shaw, M. D., Kumar, R., Saunders, R. W., Parthipan, R., Wilson, J., and Plane, J. M. C.: Atmospheric iodine levels influenced by sea surface emissions of inorganic iodine, Nat. Geosci., 6, 108-111, doi:10.1038/ngeo1687, 2013.

Chameides, W. L. and Davis, D. D.: Iodine: its possible role in tropospheric photochemistry, J. Geophys. Res.-Oceans, 85, 73837398, doi:10.1029/JC085iC12p07383, 1980.

Chance, R., Baker, A. R., Carpenter, L., and Jickells, T. D.: The distribution of iodide at the sea surface, Environ. Sci.: Processes Impacts, 16, 1841-1859, doi:10.1039/C4EM00139G, 2014.

Chuck, A. L., Turner, S. M., and Liss, P. S.: Oceanic distributions and air-sea fluxes of biogenic halocarbons in the open ocean, J. Geophys. Res.-Oceans, 110, C10022, doi:10.1029/2004jc002741, 2005.

Crowley, J. N., Ammann, M., Cox, R. A., Hynes, R. G., Jenkin, M. E., Mellouki, A., Rossi, M. J., Troe, J., and Wallington, T. J.: Evaluated kinetic and photochemical data for atmospheric chemistry: Volume V - heterogeneous reactions on solid substrates, 
Atmos. Chem. Phys., 10, 9059-9223, doi:10.5194/acp-10-90592010, 2010.

Dix, B., Baidar, S., Bresch, J., Hall, S., Schmidt, K., Wang, S.-Y., and Volkamer, R.: Detection of iodine monoxide in the tropical free troposphere, P. Natl. Acad. Sci. USA, 110, 2035-2040, doi:10.1073/pnas.1212386110, 2013.

Fiore, A. M., Naik, V., Spracklen, D. V., Steiner, A., Unger, N., Prather, M., Bergmann, D., Cameron-Smith, P. J., Cionni, I., Collins, W. J., Dalsoren, S., Eyring, V., Folberth, G. A., Ginoux, P., Horowitz, L. W., Josse, B., Lamarque, J.-F., MacKenzie, I. A., Nagashima, T., O’Connor, F. M., Righi, M., Rumbold, S. T., Shindell, D. T., Skeie, R. B., Sudo, K., Szopa, S., Takemura, T., and Zeng, G.: Global air quality and climate, Chem. Soc. Rev., 41, 6663-6683, doi:10.1039/C2CS35095E, 2012.

Fowler, D., Amann, M., Anderson, R., Ashmore, M., Cox, P., Depledge, M., Derwent, D., Grennfelt, P., Hewitt, N., Hov, O., Jenkin, M., Kelly, F., Liss, P., Pilling, M., Pyle, J., Slingo, J., and Stevenson, D.: Ground-level ozone in the 21st century: future trends, impacts and policy implications, Tech. rep., The Royal Society, 2008.

Gómez Martín, J. C., Spietz, P., and Burrows, J. P.: Spectroscopic studies of the $\mathrm{I}_{2} / \mathrm{O}_{3}$ photochemistry: Part 1: Determination of the absolute absorption cross sections of iodine oxides of atmospheric relevance, J. Photoch. Photobio. A, 176, 15-38, doi:10.1016/j.jphotochem.2005.09.024, 2005.

Gómez Martín, J. C., Spietz, P., and Burrows, J. P.: Kinetic and mechanistic studies of the $\mathrm{I}_{2} / \mathrm{O}_{3}$ photochemistry, J. Phys. Chem. A, 111, 306-320, doi:10.1021/jp061186c, 2007.

Gómez Martín, J. C., Mahajan, A. S., Hay, T. D., Prados-Roman, C., Ordonez, C., MacDonald, S. M., Plane, J. M. C., Sorribas, M., Gil, M., Mora, J. F. P., Reyes, M. V. A., Oram, D. E., Leedham, E., and Saiz-Lopez, A.: Iodine chemistry in the eastern Pacific marine boundary layer, J. Geophys. Res.-Atmos., 118, 887904, doi:10.1002/jgrd.50132, 2013.

Großmann, K., Frieß, U., Peters, E., Wittrock, F., Lampel, J., Yilmaz, S., Tschritter, J., Sommariva, R., von Glasow, R., Quack, B., Krüger, K., Pfeilsticker, K., and Platt, U.: Iodine monoxide in the Western Pacific marine boundary layer, Atmos. Chem. Phys., 13, 3363-3378, doi:10.5194/acp-13-3363-2013, 2013.

Jacob, D. J.: Heterogeneous chemistry and tropospheric ozone, Atmos. Environ., 34, 2131-2159, doi:10.1016/S13522310(99)00462-8, 2000.

Jones, C. E., Hornsby, K. E., Sommariva, R., Dunk, R. M., Von Glasow, R., McFiggans, G., and Carpenter, L. J.: Quantifying the contribution of marine organic gases to atmospheric iodine, Geophys. Res. Lett., 37, L18804, doi:10.1029/2010g1043990, 2010.

Kaltsoyannis, N. and Plane, J. M. C.: Quantum chemical calculations on a selection of iodine-containing species (IO, OIO, $\mathrm{INO}_{3}$, (IO) ${ }_{2}, \mathrm{I}_{2} \mathrm{O}_{3}, \mathrm{I}_{2} \mathrm{O}_{4}$ and $\mathrm{I}_{2} \mathrm{O}_{5}$ ) of importance in the atmosphere, Phys. Chem. Chem. Phys., 10, 1723-1733, 2008.

Kim, K.-H., Shon, Z.-H., Nguyen, H. T., and Jeon, E.-C.: A review of major chlorofluorocarbons and their halocarbon alternatives in the air, Atmos. Environ., 45, 1369-1382, doi:10.1016/j.atmosenv.2010.12.029, 2011.

Law, K. S. and Sturges, W. T.: Scientific Assessment of Ozone Depletion, 2006 Chapter 2: Halogenated Very Short-Lived Substances, Tech. rep., 2006.
Lawler, M. J., Mahajan, A. S., Saiz-Lopez, A., and Saltzman, E. S.: Observations of $\mathrm{I} 2$ at a remote marine site, Atmos. Chem. Phys., 14, 2669-2678, doi:10.5194/acp-14-2669-2014, 2014.

Lelieveld, J. and Dentener, F. J.: What controls tropospheric ozone?, J. Geophys. Res.-Atmos., 105, 3531-3551, doi:10.1029/1999JD901011, 2000.

Liu, H., Jacob, D. J., Bey, I., and Yantosca, R. M.: Constraints from $210 \mathrm{~Pb}$ and $7 \mathrm{Be}$ on wet deposition and transport in a global threedimensional chemical tracer model driven by assimilated meteorological fields, J. Geophys. Res.-Atmos., 106, 12109-12128, doi:10.1029/2000JD900839, 2001.

MacDonald, S. M., Gómez Martín, J. C., Chance, R., Warriner, S., Saiz-Lopez, A., Carpenter, L. J., and Plane, J. M. C.: A laboratory characterisation of inorganic iodine emissions from the sea surface: dependence on oceanic variables and parameterisation for global modelling, Atmos. Chem. Phys., 14, 5841-5852, doi:10.5194/acp-14-5841-2014, 2014.

Mahajan, A. S., Oetjen, H., Saiz-Lopez, A., Lee, J. D., McFiggans, G. B., and Plane, J. M. C.: Reactive iodine species in a semi-polluted environment, Geophys. Res. Lett., 36, L16803, doi:10.1029/2009GL038018, 2009.

Mahajan, A. S., Plane, J. M. C., Oetjen, H., Mendes, L., Saunders, R. W., Saiz-Lopez, A., Jones, C. E., Carpenter, L. J., and McFiggans, G. B.: Measurement and modelling of tropospheric reactive halogen species over the tropical Atlantic Ocean, Atmos. Chem. Phys., 10, 4611-4624, doi:10.5194/acp-10-4611-2010, 2010.

Mahajan, A. S., Gómez Martín, J. C., Hay, T. D., Royer, S.-J., Yvon-Lewis, S., Liu, Y., Hu, L., Prados-Roman, C., Ordóñez, C., Plane, J. M. C., and Saiz-Lopez, A.: Latitudinal distribution of reactive iodine in the Eastern Pacific and its link to open ocean sources, Atmos. Chem. Phys., 12, 11609-11617, doi:10.5194/acp-12-11609-2012, 2012.

Mao, J., Jacob, D. J., Evans, M. J., Olson, J. R., Ren, X., Brune, W. H., Clair, J. M. St., Crounse, J. D., Spencer, K. M., Beaver, M. R., Wennberg, P. O., Cubison, M. J., Jimenez, J. L., Fried, A., Weibring, P., Walega, J. G., Hall, S. R., Weinheimer, A. J., Cohen, R. C., Chen, G., Crawford, J. H., McNaughton, C., Clarke, A. D., Jaeglé, L., Fisher, J. A., Yantosca, R. M., Le Sager, P., and Carouge, C.: Chemistry of hydrogen oxide radicals $\left(\mathrm{HO}_{x}\right)$ in the Arctic troposphere in spring, Atmos. Chem. Phys., 10, 58235838, doi:10.5194/acp-10-5823-2010, 2010.

Mao, J., Paulot, F., Jacob, D. J., Cohen, R. C., Crounse, J. D., Wennberg, P. O., Keller, C. A., Hudman, R. C., Barkley, M. P., and Horowitz, L. W.: Ozone and organic nitrates over the eastern United States: sensitivity to isoprene chemistry, J. Geophys. Res.-Atmos., 118, 11256-11268, doi:10.1002/jgrd.50817, 2013.

McFiggans, G., Plane, J. M. C., Allan, B. J., Carpenter, L. J., Coe, H., and O'Dowd, C.: A modeling study of iodine chemistry in the marine boundary layer, J. Geophys. Res.-Atmos., 105, 14371-14385, doi:10.1029/1999JD901187, 2000.

McFiggans, G., Bale, C. S. E., Ball, S. M., Beames, J. M., Bloss, W. J., Carpenter, L. J., Dorsey, J., Dunk, R., Flynn, M. J., Furneaux, K. L., Gallagher, M. W., Heard, D. E., Hollingsworth, A. M., Hornsby, K., Ingham, T., Jones, C. E., Jones, R. L., Kramer, L. J., Langridge, J. M., Leblanc, C., LeCrane, J.-P., Lee, J. D., Leigh, R. J., Longley, I., Mahajan, A. S., Monks, P. S., Oetjen, H., Orr-Ewing, A. J., Plane, J. M. C., Potin, P., Shillings, A. J. L., Thomas, F., von Glasow, R., Wada, R., Whalley, L. K., and Whitehead, J. D.: Iodine-mediated coastal particle formation: 
an overview of the Reactive Halogens in the Marine Boundary Layer (RHaMBLe) Roscoff coastal study, Atmos. Chem. Phys., 10, 2975-2999, doi:10.5194/acp-10-2975-2010, 2010.

McLinden, C. A., Olsen, S. C., Hannegan, B., Wild, O., Prather, M. J., and Sundet, J.: Stratospheric ozone in 3-D models: a simple chemistry and the cross-tropopause flux, J. Geophys. Res., 105, 14653, doi:10.1029/2000JD900124, 2000.

Murray, B. J., Haddrell, A. E., Peppe, S., Davies, J. F., Reid, J. P., O'Sullivan, D., Price, H. C., Kumar, R., Saunders, R. W., Plane, J. M. C., Umo, N. S., and Wilson, T. W.: Glass formation and unusual hygroscopic growth of iodic acid solution droplets with relevance for iodine mediated particle formation in the marine boundary layer, Atmos. Chem. Phys., 12, 8575-8587, doi:10.5194/acp-12-8575-2012, 2012.

Ordóñez, C., Lamarque, J.-F., Tilmes, S., Kinnison, D. E., Atlas, E. L., Blake, D. R., Sousa Santos, G., Brasseur, G., and Saiz-Lopez, A.: Bromine and iodine chemistry in a global chemistry-climate model: description and evaluation of very short-lived oceanic sources, Atmos. Chem. Phys., 12, 1423-1447, doi:10.5194/acp12-1423-2012, 2012.

Parrella, J. P., Jacob, D. J., Liang, Q., Zhang, Y., Mickley, L. J., Miller, B., Evans, M. J., Yang, X., Pyle, J. A., Theys, N., and Van Roozendael, M.: Tropospheric bromine chemistry: implications for present and pre-industrial ozone and mercury, Atmos. Chem. Phys., 12, 6723-6740, doi:10.5194/acp-12-6723-2012, 2012.

Prados-Roman, C., Cuevas, C. A., Fernandez, R. P., Kinnison, D. E., Lamarque, J.-F., and Saiz-Lopez, A.: A negative feedback between anthropogenic ozone pollution and enhanced ocean emissions of iodine, Atmos. Chem. Phys., 15, 2215-2224, doi:10.5194/acp-15-2215-2015, 2015a.

Prados-Roman, C., Cuevas, C. A., Hay, T., Fernandez, R. P., Mahajan, A. S., Royer, S.-J., Galí, M., Simó, R., Dachs, J., Großmann, K., Kinnison, D. E., Lamarque, J.-F., and Saiz-Lopez, A.: Iodine oxide in the global marine boundary layer, Atmos. Chem. Phys., 15, 583-593, doi:10.5194/acp-15-583-2015, 2015.

Puentedura, O., Gil, M., Saiz-Lopez, A., Hay, T., Navarro-Comas, M., Gómez-Pelaez, A., Cuevas, E., Iglesias, J., and Gomez, L.: Iodine monoxide in the north subtropical free troposphere, Atmos. Chem. Phys., 12, 4909-4921, doi:10.5194/acp-12-49092012, 2012.

Read, K. A., Mahajan, A. S., Carpenter, L. J., Evans, M. J., Faria, B. V. E., Heard, D. E., Hopkins, J. R., Lee, J. D., Moller, S. J., Lewis, A. C., Mendes, L., McQuaid, J. B., Oetjen, H., Saiz-Lopez, A., Pilling, M. J., and Plane, J. M. C.: Extensive halogen-mediated ozone destruction over the tropical Atlantic Ocean, Nature, 453, 1232-1235, doi:10.1038/nature07035, 2008.

Riffault, V., Bedjanian, Y., and Poulet, G.: Kinetic and mechanistic study of the reactions of $\mathrm{OH}$ with $\mathrm{IBr}$ and HOI, J. Photoch. Photobio. A, 176, 155-161, doi:10.1016/j.jphotochem.2005.09.002, 2005.

Saiz-Lopez, A., Plane, J. M. C., McFiggans, G., Williams, P. I., Ball, S. M., Bitter, M., Jones, R. L., Hongwei, C., and Hoffmann, T.: Modelling molecular iodine emissions in a coastal marine environment: the link to new particle formation, Atmos. Chem. Phys., 6, 883-895, doi:10.5194/acp-6-883-2006, 2006.

Saiz-Lopez, A., Chance, K., Liu, X., Kurosu, T. P., and Sander, S. P.: First observations of iodine oxide from space, Geophys. Res. Lett., 34, L12812, doi:10.1029/2007g1030111, 2007.
Saiz-Lopez, A., Plane, J. M. C., Mahajan, A. S., Anderson, P. S., Bauguitte, S. J.-B., Jones, A. E., Roscoe, H. K., Salmon, R. A., Bloss, W. J., Lee, J. D., and Heard, D. E.: On the vertical distribution of boundary layer halogens over coastal Antarctica: implications for $\mathrm{O}_{3}, \mathrm{HO}_{x}, \mathrm{NO}_{x}$ and the $\mathrm{Hg}$ lifetime, Atmos. Chem. Phys., 8, 887-900, doi:10.5194/acp-8-887-2008, 2008.

Saiz-Lopez, A., Lamarque, J.-F., Kinnison, D. E., Tilmes, S., Ordóñez, C., Orlando, J. J., Conley, A. J., Plane, J. M. C., Mahajan, A. S., Sousa Santos, G., Atlas, E. L., Blake, D. R., Sander, S. P., Schauffler, S., Thompson, A. M., and Brasseur, G.: Estimating the climate significance of halogen-driven ozone loss in the tropical marine troposphere, Atmos. Chem. Phys., 12, 3939-3949, doi:10.5194/acp-12-3939-2012, 2012a.

Saiz-Lopez, A., Plane, J. M. C., Baker, A. R., Carpenter, L. J., von Glasow, R., Martin, J. C. G., McFiggans, G., and Saunders, R. W.: Atmospheric chemistry of iodine, Chem. Rev., 112, 1773-1804, doi:10.1021/cr200029u, 2012b.

Saiz-Lopez, A., Fernandez, R. P., Ordóñez, C., Kinnison, D. E., Gómez Martín, J. C., Lamarque, J.-F., and Tilmes, S.: Iodine chemistry in the troposphere and its effect on ozone, Atmos. Chem. Phys., 14, 13119-13143, doi:10.5194/acp-1413119-2014, 2014.

Sander, R.: Compilation of Henry's law constants (version 4.0) for water as solvent, Atmos. Chem. Phys., 15, 4399-4981, doi:10.5194/acp-15-4399-2015, 2015.

Sander, R., Vogt, R., Harrris, G. W., and Crutzen, P. J.: Modelling the chemistry of ozone, halogen compounds, and hydrocarbons in the arctic troposphere during spring, Tellus B, 49, 522-532, doi:10.1034/j.1600-0889.49.issue5.8.x, 1997.

Sander, S. P., Golden, D. M., Kurylo, M. J., Moortgat, G. K., Wine, P. H., Ravishankara, A. R., Kolb, C. E., Molina, M. J., Finlayson-Pitts, B. J., Huie, R. E., and Orkin, V. L.: Chemical kinetics and photochemical data for use, in: Atmospheric Studies Evaluation, Number 15, 2006.

Sander, S. P., Friedl, R. R., Abbatt, J. P. D., Barker, J. R., Burkholder, J. B., Golden, D. M., Kolb, C. E., Kurylo, M. J., Moortgat, G. K., Wine, P. H., Huie, R. E., and Orkin, V. L.: Chemical kinetics and photochemical data for use in atmospheric studies, Evaluation Number 17, Tech. rep., NASA Jet Propulsion Laboratory, 2011.

Sofen, E. D. and Evans, M. J.: Surface $\mathrm{O}_{3}$ dataset, Earth Syst. Sci. Data Discuss., in preparation, 2015.

Sommariva, R., Bloss, W. J., and von Glasow, R.: Uncertainties in gas-phase atmospheric iodine chemistry, Atmos. Environ., 57, 219-232, doi:10.1016/j.atmosenv.2012.04.032, 2012.

Spietz, P., Gómez Martín, J. C., and Burrows, J. P.: Spectroscopic studies of the $\mathrm{I}_{2} / \mathrm{O}_{3}$ photochemistry: Part 2. Improved spectra of iodine oxides and analysis of the IO absorption spectrum, J. Photoch. Photobio. A, 176, 50-67, doi:10.1016/j.jphotochem.2005.08.023, 2005.

Stuart, A. L. and Jacobson, M. Z.: A timescale investigation of volatile chemical retention during hydrometeor freezing: nonrime freezing and dry growth riming without spreading, J. Geophys. Res., 108, 4178, doi:10.1029/2001JD001408, 2003.

Vogt, R., Sander, R., Von Glasow, R., and Crutzen, P. J.: Iodine chemistry and its role in halogen activation and ozone loss in the marine boundary layer: a model study, J. Atmos. Chem., 32, 375-395, doi:10.1023/a:1006179901037, 1999. 
Volkamer, R., Baidar, S., Campos, T. L., Coburn, S., DiGangi, J. P., Dix, B., Eloranta, E. W., Koenig, T. K., Morley, B., Ortega, I., Pierce, B. R., Reeves, M., Sinreich, R., Wang, S., Zondlo, M. A., and Romashkin, P. A.: Aircraft measurements of BrO, IO, glyoxal, $\mathrm{NO}_{2}, \mathrm{H}_{2} \mathrm{O}, \mathrm{O}_{2}-\mathrm{O}_{2}$ and aerosol extinction profiles in the tropics: comparison with aircraft-/ship-based in situ and lidar measurements, Atmos. Meas. Tech., 8, 2121-2148, doi:10.5194/amt-8-2121-2015, 2015.

von Glasow, R., Sander, R., Bott, A., and Crutzen, P. J.: Modeling halogen chemistry in the marine boundary layer 2 . Interactions with sulfur and the cloud-covered MBL, J. Geophys. Res.Atmos., 107, 4323, doi:10.1029/2001JD000943, 2002.

von Glasow, R., von Kuhlmann, R., Lawrence, M. G., Platt, U., and Crutzen, P. J.: Impact of reactive bromine chemistry in the troposphere, Atmos. Chem. Phys., 4, 2481-2497, doi:10.5194/acp-42481-2004, 2004.

Voulgarakis, A., Naik, V., Lamarque, J.-F., Shindell, D. T., Young, P. J., Prather, M. J., Wild, O., Field, R. D., Bergmann, D., CameronSmith, P., Cionni, I., Collins, W. J., Dalsøren, S. B., Doherty, R. M., Eyring, V., Faluvegi, G., Folberth, G. A., Horowitz, L. W., Josse, B., MacKenzie, I. A., Nagashima, T., Plummer, D. A., Righi, M., Rumbold, S. T., Stevenson, D. S., Strode, S. A., Sudo, K., Szopa, S., and Zeng, G.: Analysis of present day and future $\mathrm{OH}$ and methane lifetime in the ACCMIP simulations, Atmos. Chem. Phys., 13, 2563-2587, doi:10.5194/acp-13-25632013, 2013.

Wang, S.-Y., Schmidt, J., Baidar, S., Coburn, S., Dix, B., Koenig, T., Apel, E., Bowdalo, D., Campos, T., Eloranta, E., Evans, M., DiGangii, J., Zondlo, M., Gao, R.-S., Haggerty, J., Hall, S., Hornbrook, R., Jacob, D., Morley, B., Pierce, B., Reeves, M., Romashkin, P., ter Schure, A., and Volkamer, R.: Active and widespread halogen chemistry in the tropical and subtropical free troposphere, P. Natl. Acad. Sci. USA, 112, 9281-9286, doi:10.1073/pnas.1505142112, 2015.
Wesely, M. L.: Parameterization of surface resistances to gaseous dry deposition in regional-scale numerical models, Atmos. Environ., 23, 1293-1304, doi:10.1016/0004-6981(89)90153-4, 1989.

WOUDC: WOUDC Ozone Monitoring Community, World Meteorological Organization-Global Atmosphere Watch Program (WMO-GAW)/World Ozone and Ultraviolet Radiation Data Centre (WOUDC) [Data], doi:10.14287/10000001, available at: http://www.woudc.org, last access: 1 October 2014.

Young, P. J., Archibald, A. T., Bowman, K. W., Lamarque, J.-F., Naik, V., Stevenson, D. S., Tilmes, S., Voulgarakis, A., Wild, O., Bergmann, D., Cameron-Smith, P., Cionni, I., Collins, W. J., Dalsøren, S. B., Doherty, R. M., Eyring, V., Faluvegi, G., Horowitz, L. W., Josse, B., Lee, Y. H., MacKenzie, I. A., Nagashima, T., Plummer, D. A., Righi, M., Rumbold, S. T., Skeie, R. B., Shindell, D. T., Strode, S. A., Sudo, K., Szopa, S., and Zeng, G.: Preindustrial to end 21st century projections of tropospheric ozone from the Atmospheric Chemistry and Climate Model Intercomparison Project (ACCMIP), Atmos. Chem. Phys., 13, 20632090, doi:10.5194/acp-13-2063-2013, 2013.

Ziska, F., Quack, B., Abrahamsson, K., Archer, S. D., Atlas, E., Bell, T., Butler, J. H., Carpenter, L. J., Jones, C. E., Harris, N. R. P., Hepach, H., Heumann, K. G., Hughes, C., Kuss, J., Krüger, K., Liss, P., Moore, R. M., Orlikowska, A., Raimund, S., Reeves, C. E., Reifenhäuser, W., Robinson, A. D., Schall, C., Tanhua, T., Tegtmeier, S., Turner, S., Wang, L., Wallace, D., Williams, J., Yamamoto, H., Yvon-Lewis, S., and Yokouchi, Y.: Global sea-toair flux climatology for bromoform, dibromomethane and methyl iodide, Atmos. Chem. Phys., 13, 8915-8934, doi:10.5194/acp13-8915-2013, 2013. 